\title{
Contamination of Coliform Bacteria in Water and Fishery Resources in Manila Bay Aquaculture Farms
}

\author{
Raña, Joan A.*, Domingo, Jonacel E., Opinion, April \\ Grace R., and Cambia, Flordeliza D. \\ Fisheries Post Harvest Research and Development Division, \\ National Fisheries Research and Development Institute, Quezon City, Philippines 1103
}

\begin{abstract}
The coliform group of bacteria is widely used as an indicator of pollution related to the presence of pathogenic bacteria linked to fecal contamination, which poses great health risk. This study aimed to establish baseline information on the coliform contamination in water and fishery resources in Manila Bay aquaculture farms. Water samples and major aquaculture commodities were collected twice per season from representative aquafarms in the coastal provinces of the bay and were analyzed for total coliform (TC), fecal coliform (FC), and E. coli (EC) using the Multiple Tube Fermentation method of the Bacteriological Analytical Manual. TC, FC, and EC in water were found higher during the wet season, their average concentrations being 8,747, 2,808, and 1, $216 \mathrm{MPN} / 100 \mathrm{~mL}$, respectively; while those in the dry being 6,255, 1,223, and $286 \mathrm{MPN} / 100 \mathrm{~mL}$, respectively. More samples exceeded the DENR Standard Limit for TC $(5,000 \mathrm{MPN} / 100 \mathrm{~mL})$ in the wet season than in the dry season (roughly 25\% vs 10\%). Farmed fishery resources, on the other hand, had higher EC concentrations during the dry season. The following are the percentages of samples that exceeded DENR Standards: $25 \%$ of mussels, $24.44 \%$ of shrimps, $16 \%$ of tilapia, $14.67 \%$ of oysters, $8.89 \%$ of crabs, and $6.67 \%$ of milkfish.
\end{abstract}

Keywords: Manila Bay, farmed fishery resources, coliforms, aquaculture farms 


\section{INTRODUCTION}

Coliforms are facultative anaerobic, gram-negative, lactose-fermenting, nonspore-forming rods present in the environment and in the intestinal tract of humans and other animals in large numbers (Madigan et $a l, 2012)$. Widely used as an indicator of microbial contamination, the coliform group of bacteria includes both the pathogenic and non-pathogenic forms (Forsythe, 2010).

Total coliforms, which encompass bacteria common in soils, plants, and animals, including both fecal coliforms and Escherichia coli, react to the natural environment and treatment processes similar to pathogens; the reason they are the primarily used indicators of contamination simple enough to identify (Treyens, 2009). Taking a closer look at the coliform bacteria gives an estimate of the number/concentration of pathogenic bacteria in the sample (Henze et al, 2008).

The US Environmental Protection Agency in 2012 had recommended the use of thermo-tolerant group of coliforms linked to the presence of fecal matter commonly known as fecal coliforms to monitor water quality standards. While fecal coliforms do not necessarily cause illness, its presence in high numbers suggests higher risk of contracting disease-causing bacteria and/or viruses including pathogenic Escherichia coli (Oram, 2014). The US Environmental Protection Agency recommends the determination of Escherichia coli or Enterococci to further identify health risk.

Escherichia coli, commonly known as E. coli, is a typically harmless bacterium naturally found in the intestines of warm-blooded animals including humans, and plays a vital role in the digestion, absorption of essential nutrients, and production of Vitamin K and B (Hayhurst, 2004). Characterized by its ability to utilize sugars as a source of energy, E. coli can live with or without oxygen (Snyder, 2008).

Although mutualistic with its host, certain E. coli strains are pathogenic and can cause illnesses including urinary tract infections, sepsis/meningitis, and enteric/diarrheal diseases in immunosuppressed hosts (Nataro and Kaper, 1998). With a minimum infectious dose of 104 cells and four enterovirulent classes, namely Enteropathogenic E. coli (EPEC), Enteroaggregative E. coli (EAggEC), Enteroinvasive E. coli (EIEC), Enterotoxigenic E. coli (ETEC), and Enterohemorrhagic E. coli (EHEC), it can be a cause of diarrhea. Enteropathogenic E. coli (EPEC) causes severe diarrhea in infants 17-72 hours upon ingestion, which can last for over two weeks, resulting in death, if dehydration is severe. Enteroinvasive E. coli (EIEC), with an infectious dose of 104 to 105 cells has symptoms similar to shigellosis - chills, fever, headache, muscle pain, abdominal cramps, and profuse diarrhea - evident 8-24 hours upon infection. Enterotoxigenic $E$. coli (ETEC), commonly known as traveler's diarrhea has an infectious dose of 108 to 1010 cells within 8-44 hours, causing severe diarrhea without fever leading to dehydration. Enterohemmorraghic E. coli (EHEC), causes bloody diarrhea, central nervous system involvement in which patients develop blood clots in the brain and frequently results in death, and uremic syndrome in children, the leading cause of kidney failure in children, and may ultimately lead to death (Centers for Diseases Control and Prevention, 2015).

Manila Bay is a semi-enclosed estuary highly regarded for its usefulness to different industries including aquaculture. Fish, fish pens, and shellfish-growing areas are widespread in provinces along the bay covering an 
aquaculture area of almost 60,000 ha (Perez et al, 1999). According to the valuation study of PEMSEA (2006), 59\% of Manila Bay's current economic value of 8.3 billion pesos is accounted for by aquaculture alone. However, the bay is currently beset with environmental problems due to pollution. Runoffs from agricultural, domestic, and industrial wastes are concentrated in the bay area most likely indicating presence of pathogenic microorganisms in the water as well as in the fishery resources therein.

Reports on bacterial contamination in several parts the bay had been recorded in the past years. PEMSEA (2006) reported that fecal coliform levels at the eastern part of Manila Bay has exceeded the criteria set by the Department of Environment and Natural Resources (DENR DAO 34) for non-contact recreation of $5,000 \mathrm{MPN} / 100 \mathrm{~mL}$ by 150 times and an alarming 900 times for swimming $(1,000$ MPN/100mL). The western side of the bay where values were much lower than those at the eastern side, also failed the criteria occasionally. In addition, shellfish collected from Bulacan, Bacoor, Kawit, Naic, and Parañaque exceeded the European Union Guideline for fecal coliform of $300 \mathrm{MPN} / 100 \mathrm{~g}$ by 1.3 to 2, 667 times, or 52 times on average. In 2014, Parco reported that fecal coliform levels of more than $100,000 \mathrm{MPN} / 100 \mathrm{~mL}$, have greatly exceeded the DENR Standard of $200 \mathrm{MPN} / 100 \mathrm{~mL}$ for Class B Sea Water, in Manila Bay.

The presence of pathogenic bacteria in the bay can affect post-harvest quality, not just of wild fishery resources, but also of aquaculture commodities, as the water for fish farming is also sourced from the bay and its river tributaries. Health of the consumers, therefore, is greatly at risk especially since people tend to consume more fishery resources because of its healthier reputation. In a report by the BFAR (2011), fish and fishery products consumption amounts to 38 kilograms per year per capita, even higher than the consumption of meat products, which only amounts to 22 kilograms per year per capita. However, few studies have been done to assess the microbial levels of aquaculture commodities as well as the water where it is farmed. In fact, gaps on the water quality standards of the Philippines, given by the lack of standard limits for E. coli and/or Enterococci in spite of its risks, have been noticed.

This study aims to detect and quantify coliform, fecal coliform, and Escherichia coli levels in water and fishery resources in aquaculture farms around Manila Bay. Results gathered will be compared with existing standards and will serve as a significant baseline data for the establishment of limits for fecal coliform and E. coli in fishery water. The study also intends to determine and compare the spatial and seasonal (wet and dry) microbial distribution in water and fishery resources in aquaculture farms around Manila Bay.

\section{Methodology}

The blocking strategy and sampling sites used in Chapter 2 were employed in this study. Forty-seven pre-identified aquaculture farms and coastal areas were sampled twice for each season - September and November 2014 for the wet season, and February and April 2015 for the dry. River tributaries of the aquaculture farms were also sampled for comparison.

Water samples of about $250 \mathrm{~mL}$ were collected in composite from the deepest sections of the area using an improvised water collector and transferred in appropriately-labeled sterile $250 \mathrm{~mL}$ borosilicate bottles containing $0.25 \mathrm{~mL} \mathrm{3 \%}$ sodium thiosulfate. Aseptic technique was observed throughout the collection. Samples were placed in a temperature-controlled cooler kept at 0 to $4^{\circ} \mathrm{C}$ for 
transport. Samples were analyzed in the laboratory within 6 hours from the time of collection (APHA, AWWA, and WEF, 1999).

Freshly harvested fish and shellfish samples of at least 500 grams per species were put separately into appropriately-labeled sterile re-sealable polyethylene bags and placed in a temperature-controlled cooler kept at $0^{\circ} \mathrm{C}$ to $4^{\circ} \mathrm{C}$ for transport. Aseptic technique was observed throughout the collection. Samples were analyzed in the laboratory within 24 hours from the time of collection.

Six kinds of farmed fishery resources were collected from the aquaculture farms for the study, namely tilapia, milkfish, shrimp, crab, mussel, and oyster. However, sample species and number of samples collected per site were variable as sample collection was solely dependent on availability. Table 5.1 shows the summary of fishery commodities collected.

Multiple tube fermentation method of analysis for total coliform, fecal coliform, and Escherichia coli was employed, as is recommended in DAO 34 (APHA, AWWA, \& WEF, 1999; BAM, 2002). Results were interpreted using the Most Probable Number (MPN) table and expressed as MPN/g for the fish and fishery resources, and MPN/100mL for the water samples.

T-test was used to compare results for the microbiological analyses - total coliform, fecal coliform, and Escherichia coli - in pond and river for each block in each season. The same test was employed in determining significant differences in bacterial level between the wet and the dry season in each of the blocks. Analysis of Variance (ANOVA) was utilized for the comparison of results of each fishery commodity in different sources or sites during a particular season, given that fishery commodity was taken from more than two sites. Otherwise, the t-test was used. All values were transformed to $\log 10$ for analysis. Raw data were used for the summary of the means.

Table 5.1. Summary of the fishery commodities collected for the study.

\begin{tabular}{llrr}
\hline \multirow{2}{*}{ TYPE } & COMMODITY & \multicolumn{2}{c}{ NUMBER OF SAMPLES } \\
\cline { 3 - 4 } & & WET & DRY \\
\hline Finfish & Milkfish & 70 & 20 \\
& Tilapia & 40 & 35 \\
Crustacean & Shrimp & 20 & 25 \\
& Crab & 20 & 25 \\
Bivalves & & 35 & 40 \\
& Oyster & 20 & 40 \\
\hline
\end{tabular}




\section{Results}

Seasonal and spatial distribution of coliform bacteria in pond water and water sources

\section{TOTAL COLIFORM}

Figures 5.1a to 5.1d show total coliform concentrations in Manila Bay aquaculture farms and coastal areas in September 2014, November 2014, February 2015, and April 2015, respectively.

Total coliform levels recorded in September 2014 ranged from $49 \mathrm{MPN} / 100 \mathrm{~mL}$ to 54 , $000 \mathrm{MPN} / 100 \mathrm{~mL}$, highest in Calero and Tawiran, Eastern Bulacan and Sapang Kawayan, Pampanga; and lowest in Camachile, Southern Bataan. Thirty four percent of the samples collected in this month failed to meet DENR Standard Limit for Total Coliform Concentration for Class SC Water of 5, $000 \mathrm{MPN} / 100 \mathrm{~mL}$ (DAO 34) broken down as follows: $4.55 \%$ in Eastern Bulacan, Western Bulacan, and Northern Bataan; $13.64 \%$ in Cavite; and 6.82\% in Pampanga.

November 2014 total coliform levels ranged from $6.8 \mathrm{MPN} / 100 \mathrm{~mL}$ to $160,000 \mathrm{MP}$ $\mathrm{N} / 100 \mathrm{~mL}$, the highest noted in San Antonio, Pampanga and the lowest in Sta. Elena, Southern Bataan. Sixteen percent of the samples collected in this month exceeded the Standard Limit for Total Coliform: $2.27 \%$ in Western Bulacan and Southern Bataan, 6.82\% in Cavite, and $4.55 \%$ in Pampanga. Total coliform levels in this month were relatively lower with $22.73 \%$ of the aquaculture farms within the $<1.8-100$ MPN/100 mL range as compared to $9.09 \%$ of the aquaculture farms within the same range for September 2014. A majority of the results, $22.73 \%$, were within $235-800 \mathrm{MPN} / 100 \mathrm{~mL}$.

February 2015 total coliform levels with only $8.51 \%$ of the results exceeded the DENR
Standards for total coliform with a range of $<1.8 \mathrm{MPN} / 100 \mathrm{~mL}$ to $>160,000 \mathrm{MPN} / 100 \mathrm{~mL}$. The highest was observed in Batang 2, Pampanga and the lowest in Samal (Coastal Area), Northern Bataan. Samples that exceeded DENR standards were observed in Northern Bataan $(2.12 \%)$, Cavite $(2.12 \%)$, and Pampanga $(4.26 \%)$. Total coliform levels during this month were relatively lower with $34 \%$ of the aquaculture farms within the range of $<1.8$ $100 \mathrm{MPN} / 100 \mathrm{~mL}$ as against only $29.55 \%$ of the aquaculture farms within the same interval on April 2015.

Total coliform levels in April 2015 ranged from $7.8 \mathrm{MPN} / 100 \mathrm{~mL}$ to $>160,000$ MPN/100mL, highest noted in Capitangan, Northern Bataan and lowest in San Roque (Coastal Area), Western Bulacan. Eleven percent of the collected samples failed to meet the DENR Standard Limit for Total Coliform: $2.22 \%$ in Northern Bataan and $4.44 \%$ in both Southern Bataan and Cavite.

To determine if total coliform concentrations in the ponds are significantly different from that of their water sources, simultaneous collection of samples from the water sources of the ponds was performed. The difference in the total coliform concentration in the pond and its river tributary or water source is indicative of the flow of bacterial contamination. A higher total coliform concentration in the pond suggests that the pond may contaminate its river tributary, which in turn flows into Manila Bay, while a higher total coliform concentration in the river tributary or water source suggests otherwise. Figures 5.2 and 5.3 show the total coliform concentrations of the ponds, coastal areas, and their river tributaries or water sources of all the blocks during the first and second replicates of the dry season (February and April 2015), respectively. As can be observed, total coliform concentrations were consistently lower in the pond than in their river tributaries in all the blocks in both 


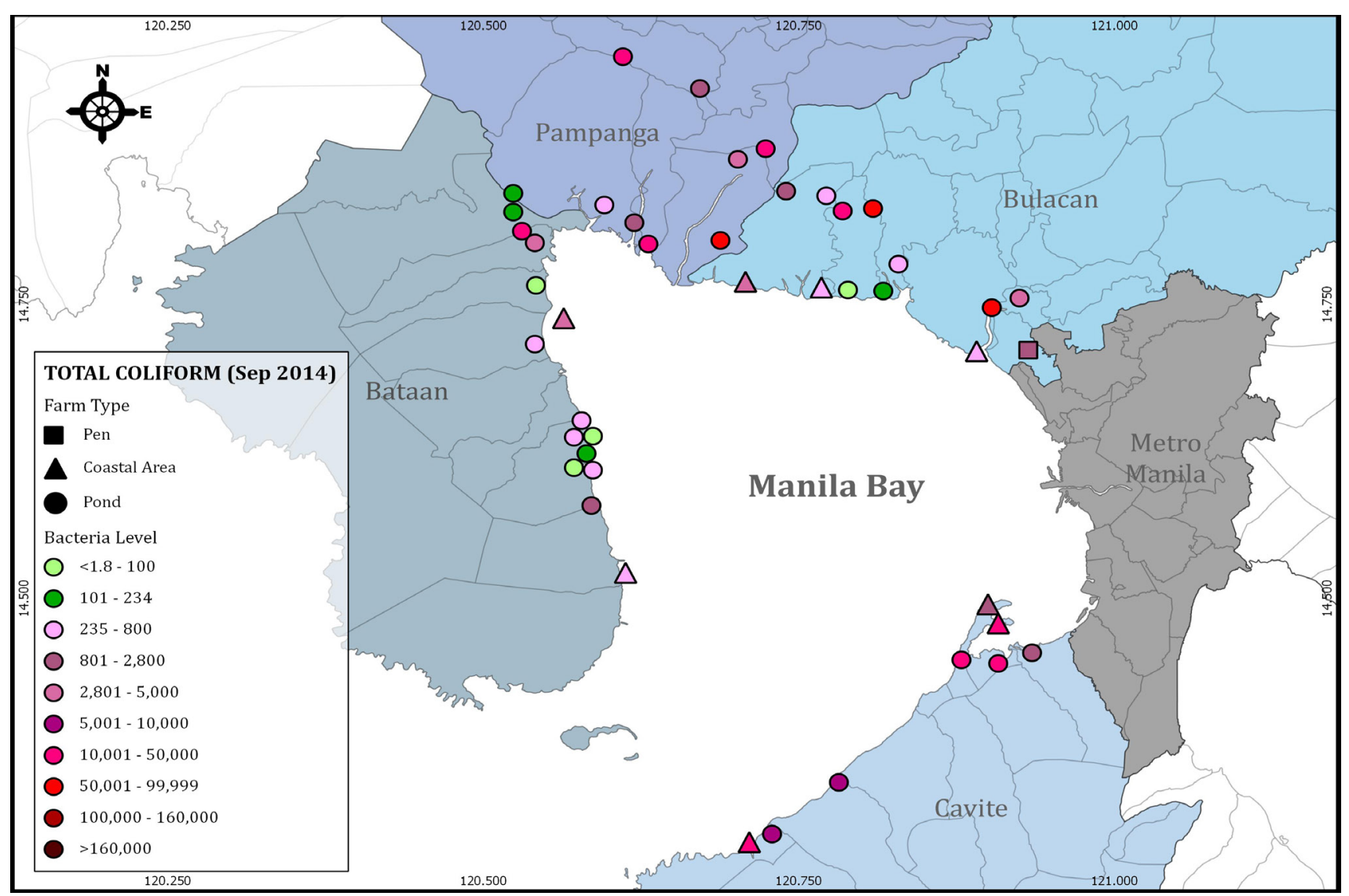

Figure 5.1a. Total coliform levels in Manila Bay aquaculture farms in September 2014.

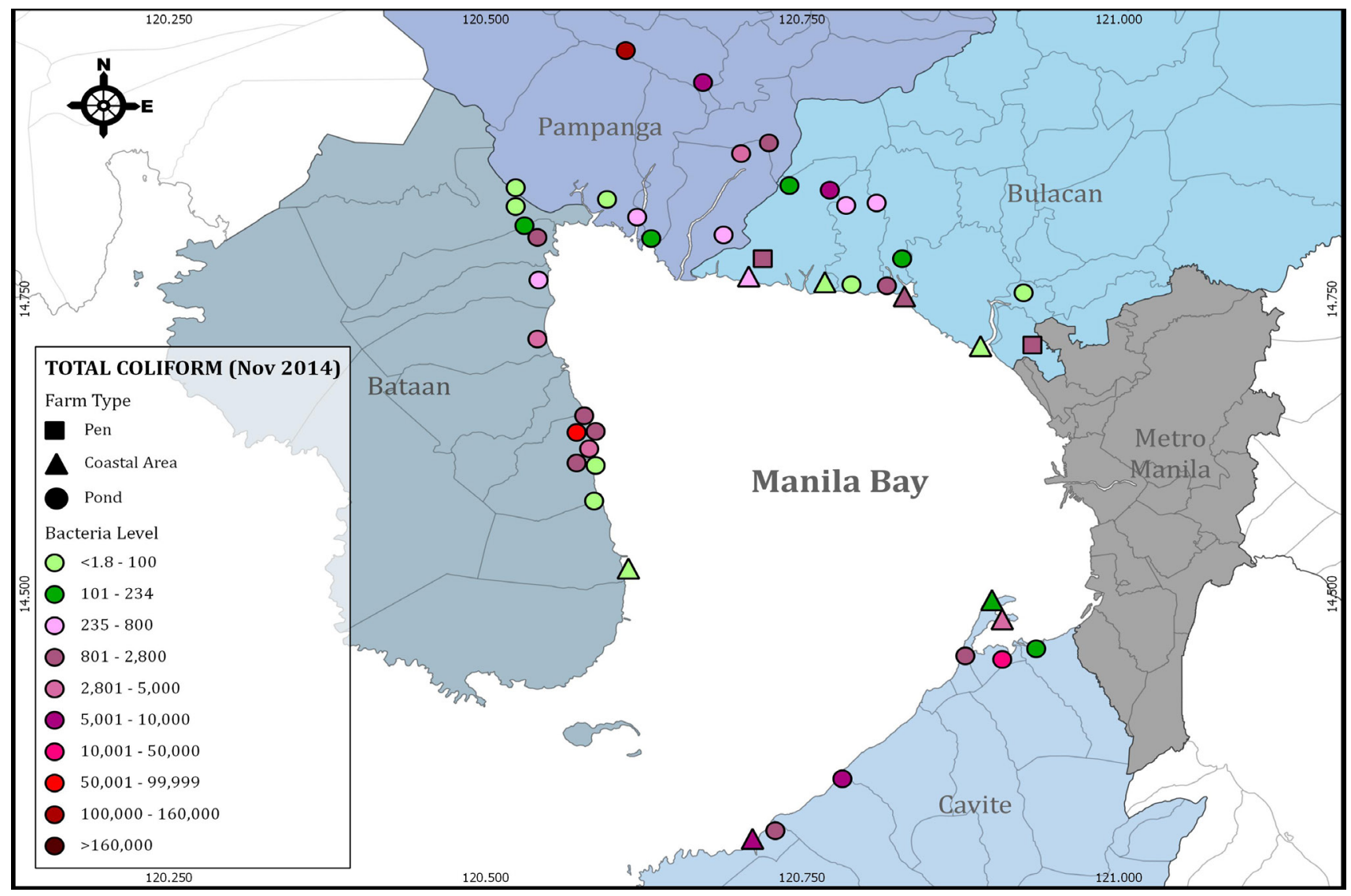

Figure 5.1b. Total coliform levels in Manila Bay aquaculture farms in November 2014. 


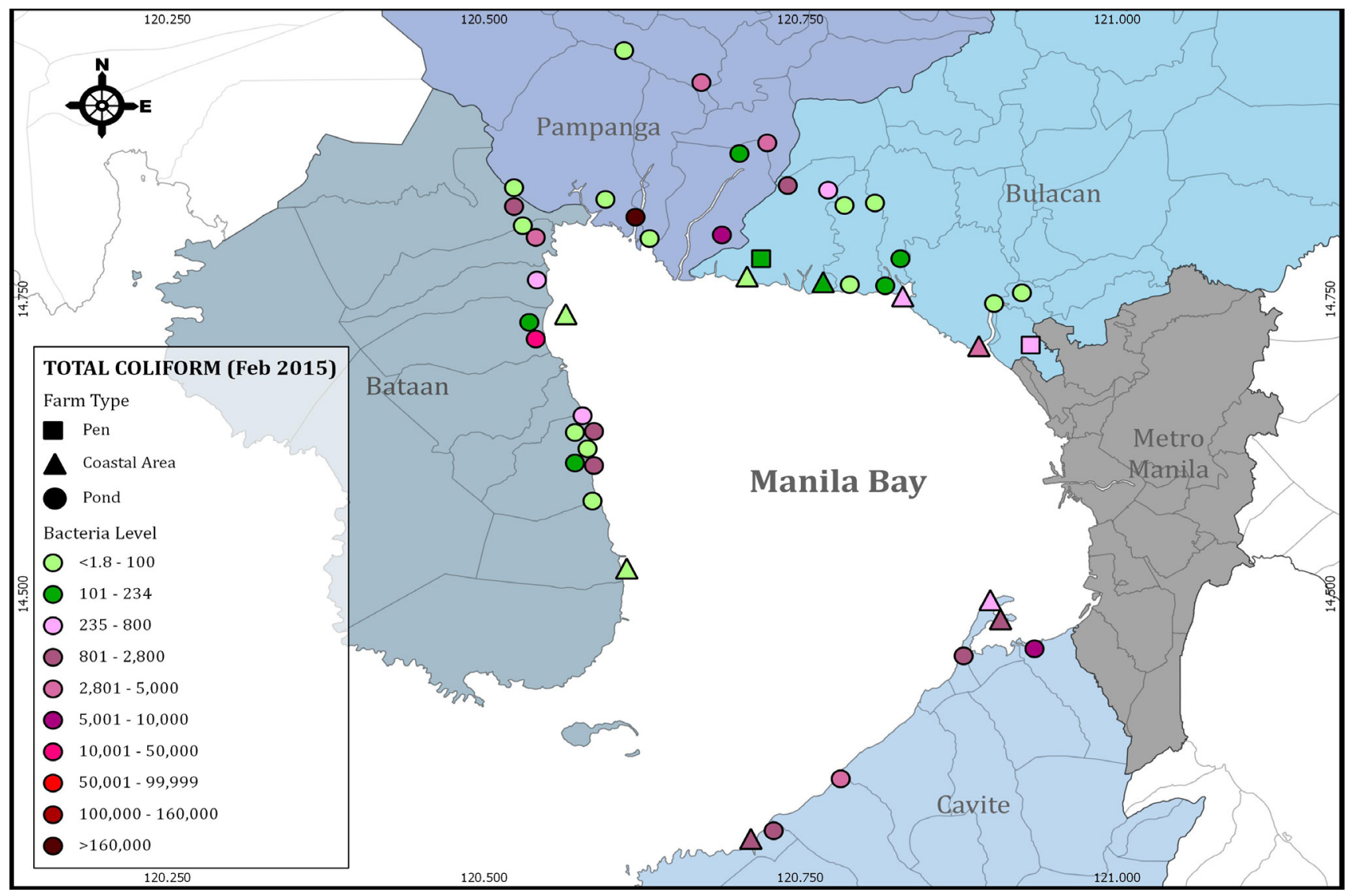

Figure 5.1c. Total coliform levels in Manila Bay aquaculture farms in February 2015.

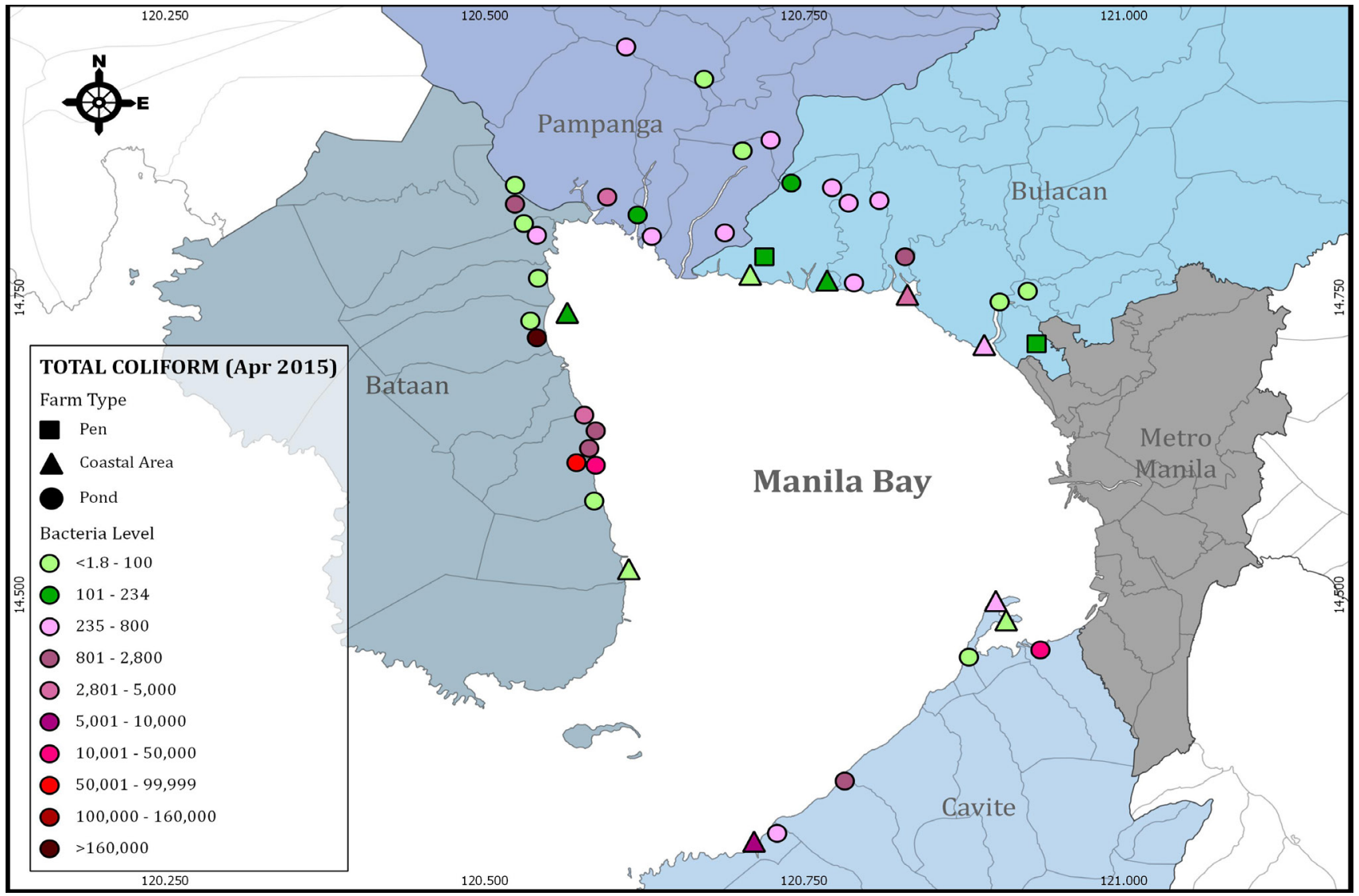

Figure 5.1d. Total coliform levels in Manila Bay aquaculture farms in April 2015. 


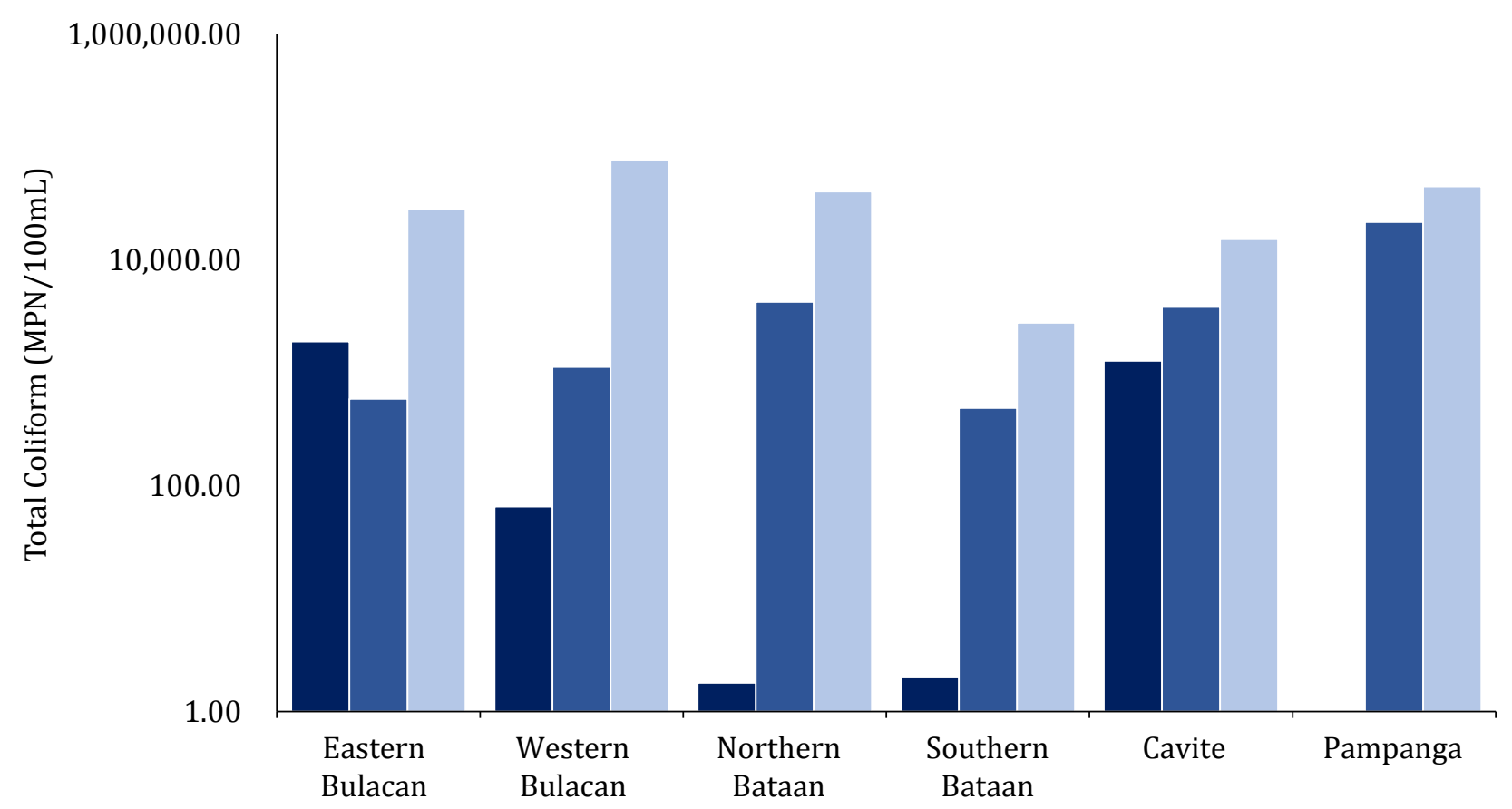

Figure 5.2. Total coliform levels in ponds, coastal areas, and river tributaries or water sources in February 2015. Coastal Area Pond Water Source

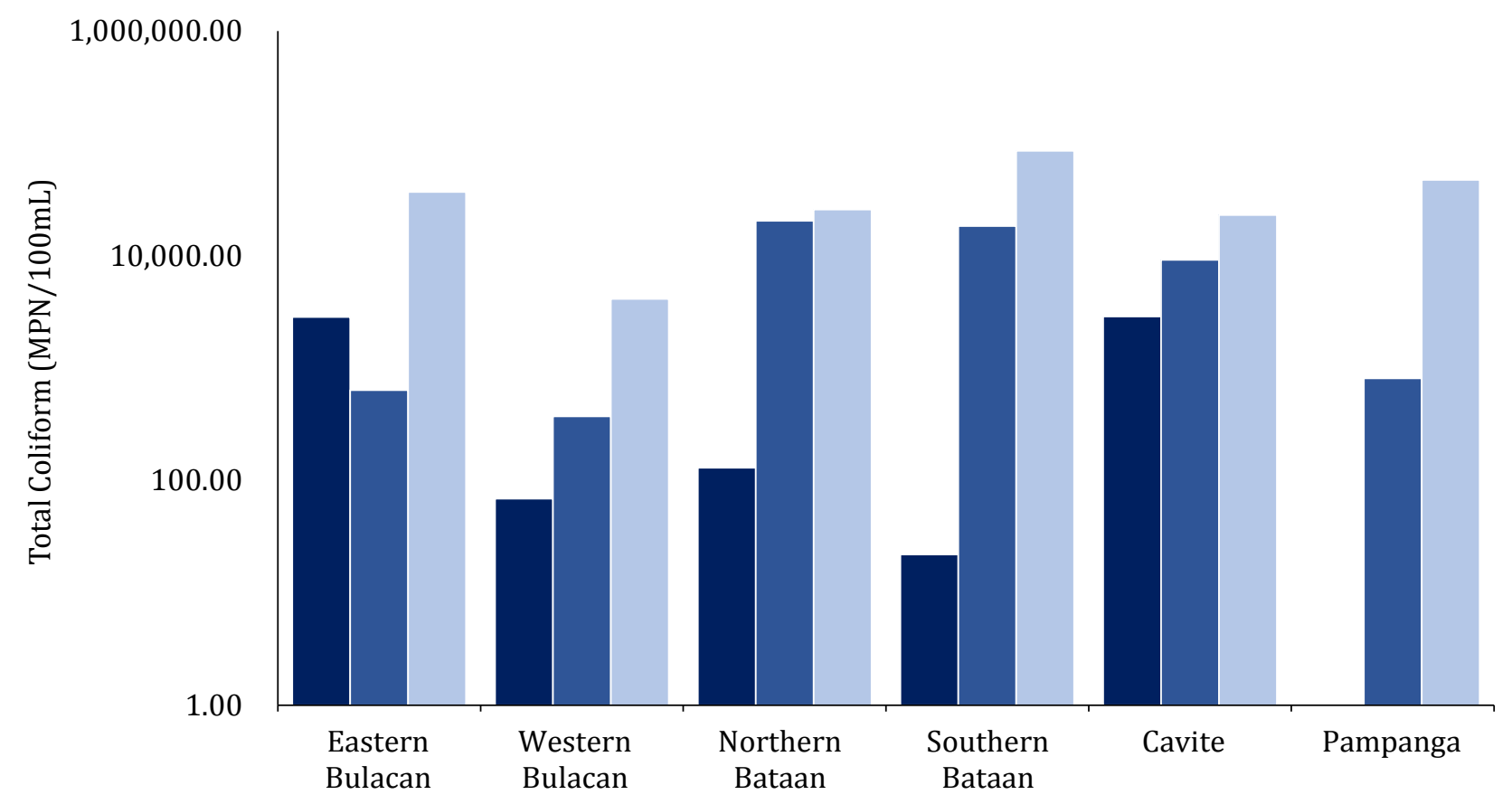

Figure 5.3. Total coliform levels in ponds, coastal areas, and river tributaries or water sources in April 2015. 
replicates of the dry season. Comparison of the total coliform levels between the water sources and the ponds of the following areas showed that the former are significantly higher than the latter: Eastern Bulacan $(p<0.01)$ and Northern Bataan $(\mathrm{p}<0.05)$ in February and April 2015; Southern Bataan $(\mathrm{p}<0.05)$ in February 2015; and Western Bulacan, Cavite, and Pampanga $(\mathrm{p}<0.05)$ in April 2015.

\section{FECAL COLIFORM}

Fecal coliform levels in Manila Bay aquaculture farms and coastal areas for September 2014, November 2015, February 2015, and April 2015 are shown in Figures 5.4a to $5.4 \mathrm{~d}$, respectively.

September 2014 fecal coliform levels ranged from 11 to 49, $000 \mathrm{MPN} / 100 \mathrm{~mL}$, the highest noted in Consuelo II, Pampanga and lowest in Wawa, Northern Bataan and Camachile, Southern Bataan. Southern Bataan had the lowest fecal coliform concentrations among the blocks with a mean concentration of $153 \mathrm{MPN} / 100 \mathrm{~mL}$, while Pampanga with an average concentration of 14, $537 \mathrm{MP}$ $\mathrm{N} / 100 \mathrm{~mL}$ had the highest.

The November 2014 fecal coliform levels, which ranged from $<1.8 \mathrm{MPN} / 100 \mathrm{~mL}$ to 7, $900 \mathrm{MPN} / 100 \mathrm{~mL}$, highest were found in San Isidro II, Western Bulacan and Marulas, Cavite, and lowest at Wawa, Northern Bataan and Sta. Elena, Southern Bataan. Highest concentrations were in Cavite (average, 1, 936 MPN/100mL), while the lowest were noted in Southern Bataan (average, $248 \mathrm{MPN} / 100 \mathrm{~mL}$ ).

February 2015 fecal coliform in Manila Bay aquaculture farms and coastal areas were from $<1.8$ to $7,900 \mathrm{MPN} / 100 \mathrm{~mL}$, highest in Sapang Kawayan, Pampanga and lowest in Samal (Coastal Area), Northern Bataan, Camachile, Southern Bataan, and Consuelo II and San Antonio, Pampanga. The levels in this month were the lowest observed among all the sampling months. Lowest concentrations were observed in Northern Bataan (average, 202 MPN/100mL). Highest levels were noted in Pampanga (average, 1, $664 \mathrm{MPN} / 100 \mathrm{~mL}$ ).

The levels in April 2015 ranged from $<1.8$ to 54, $000 \mathrm{MPN} / 100 \mathrm{~mL}$, highest in Capitangan, Northern Bataan and lowest in Bangkal Pugad, Pampanga. Those observed in Western Bulacan (average, $67 \mathrm{MPN} / 100 \mathrm{~mL}$ ) were the lowest, while the concentrations in Southern Bataan (average, of 3, $377 \mathrm{MP}$ $\mathrm{N} / 100 \mathrm{~mL}$ ) were the highest.

Fecal coliform concentrations of the ponds, coastal areas, and the river tributaries or water sources of all the blocks in February and April 2015 are shown in Figures 5.5 and 5.6 , respectively. It should be noted that fecal coliform concentrations in water sources were consistently higher than those of ponds in all the blocks in both replicates of the dry season. A comparison of the fecal coliform levels between the water sources and the ponds of the following areas showed that the former were significantly higher than the latter in February 2015: Eastern Bulacan $(\mathrm{p}<0.01)$, Western Bulacan $(p<0.05)$, Northern Bataan $(p<0.01)$, Southern Bataan $(p<0.05)$, Cavite $(p<0.05)$, and Pampanga $(\mathrm{p}<0.05)$. On the other hand, only Eastern Bulacan, Northern Bataan, and Pampanga had significantly higher fecal coliform concentrations in the water sources than in the ponds in April $2015(\mathrm{p}<0.05)$.

\section{Escherichia coli}

Escherichia coli concentrations in Manila Bay Aquaculture farms and coastal areas in September 2014, November 2014, February 2015, and April 2015 are shown in Figures 5.7a to $5.7 \mathrm{~d}$, respectively.

E. coli concentrations in September 2014 (range, $<1.8$ to $49,000 \mathrm{MPN} / 100 \mathrm{~mL}$ ) were 


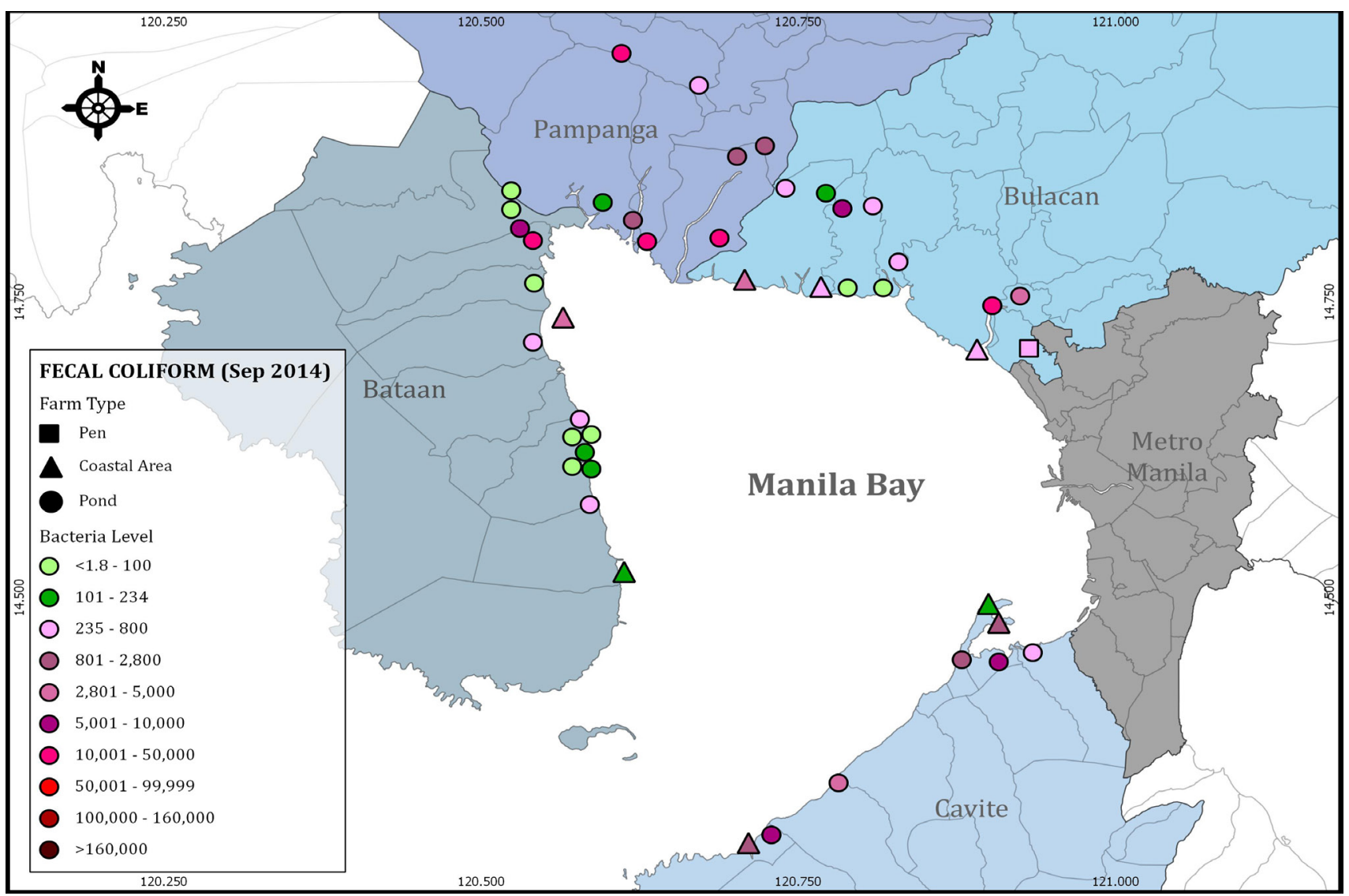

Figure 5.4a. Fecal coliform levels in Manila Bay aquaculture farms in September 2014.

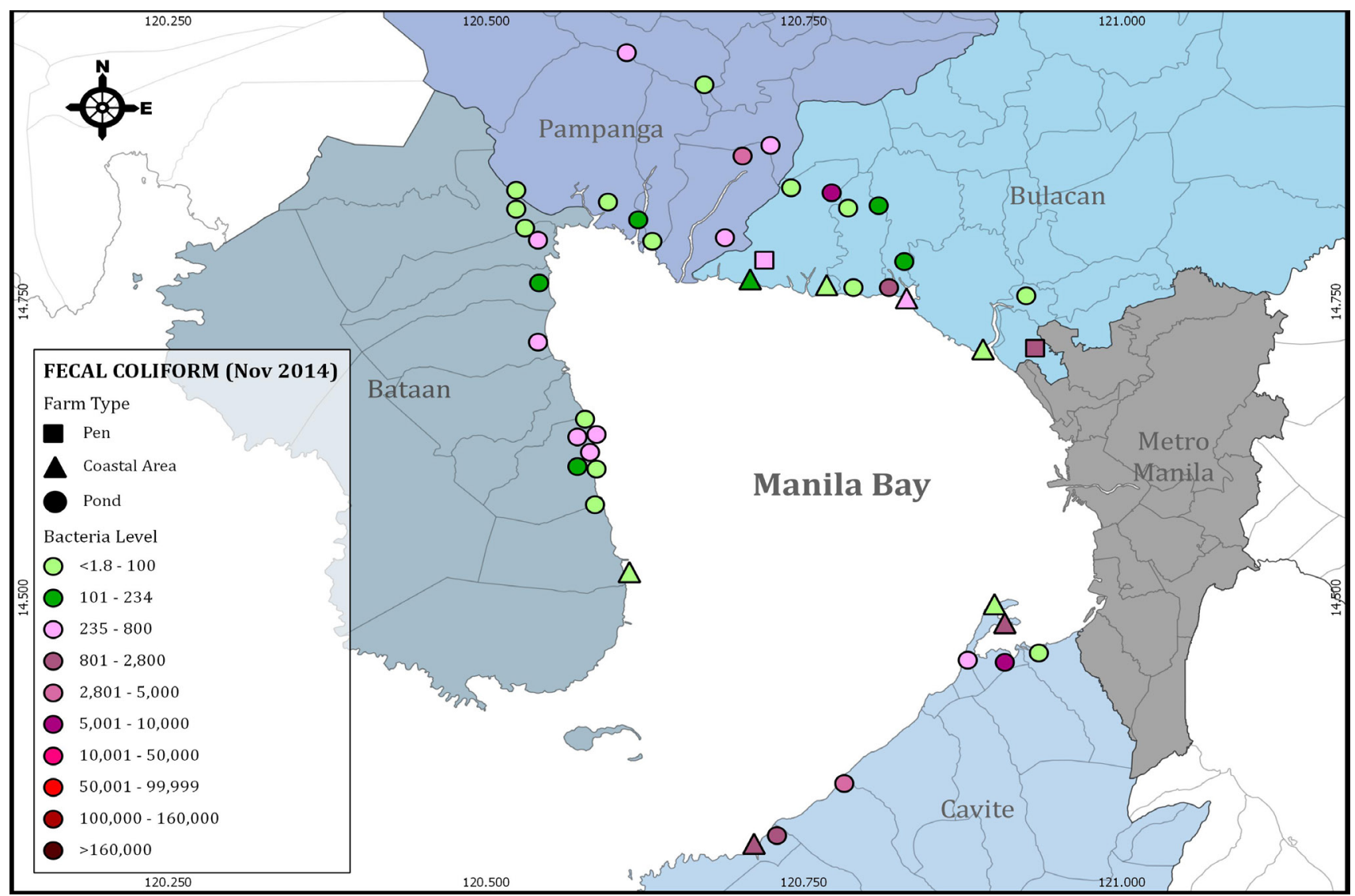

Figure 54b. Fecal coliform levels in Manila Bay aquaculture farms in November 2014. 


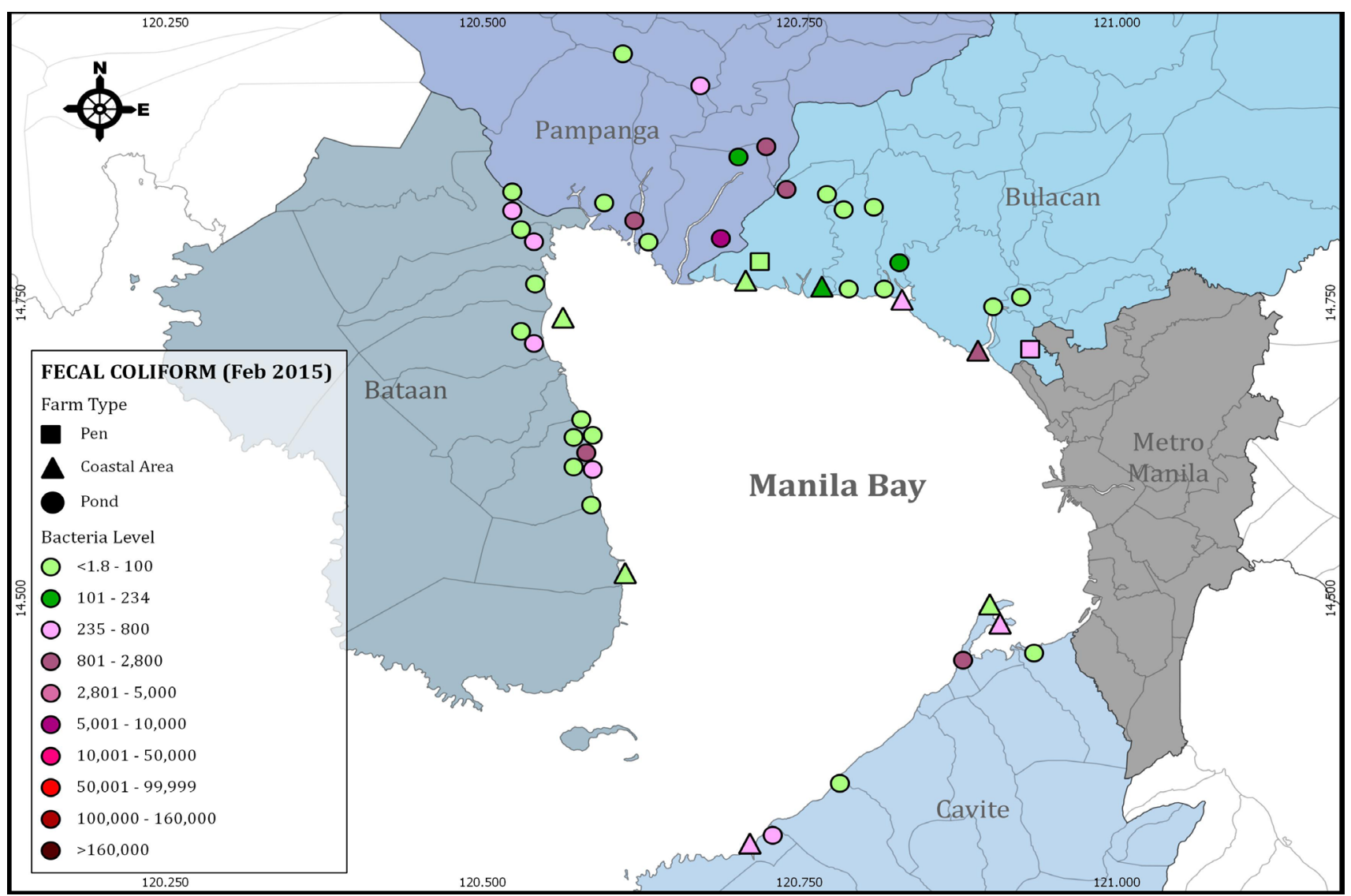

Figure 5.4c. Fecal coliform levels in Manila Bay aquaculture farms in February 2015.

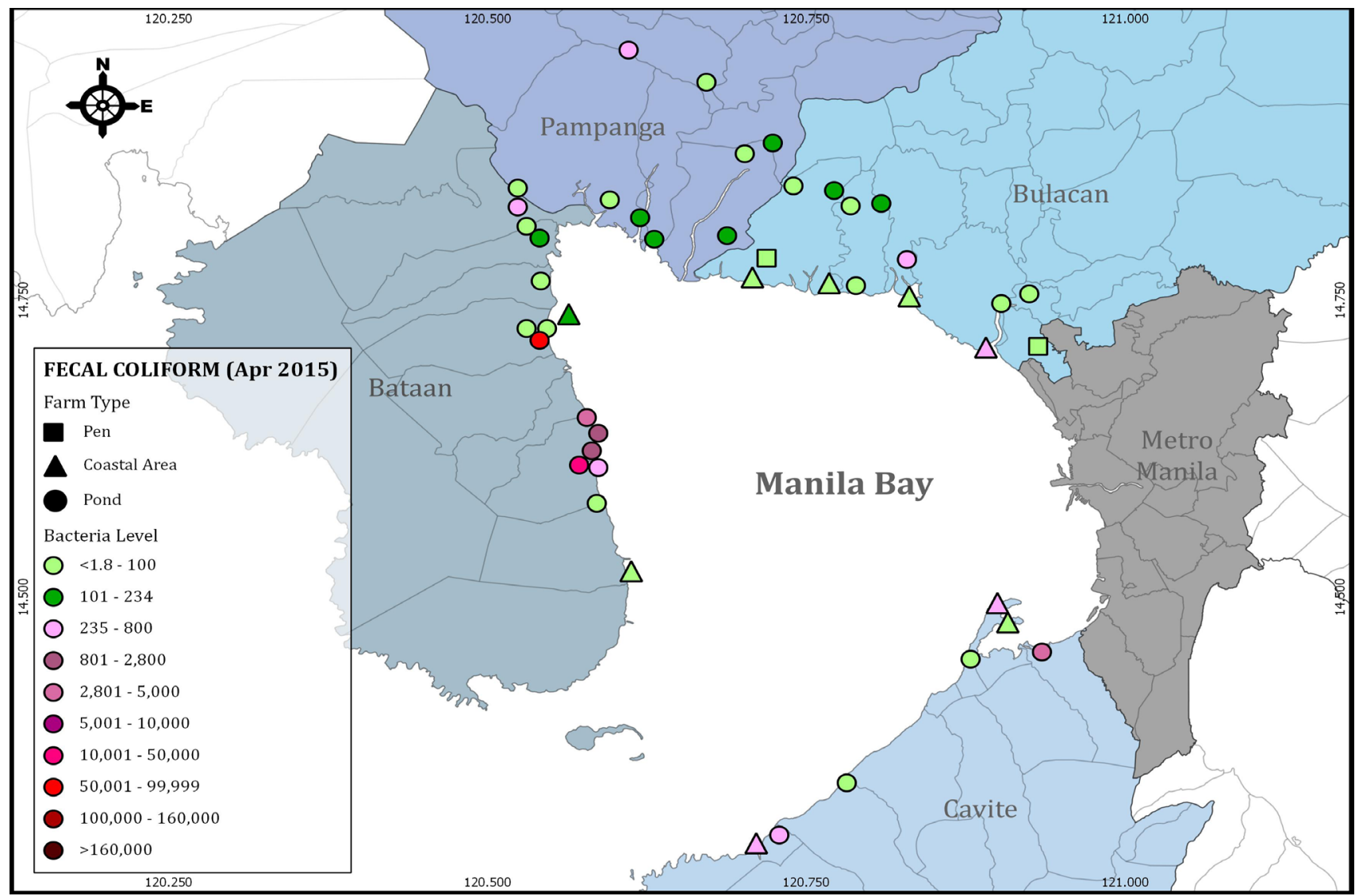

Figure 5.4d. Fecal coliform levels in Manila Bay aquaculture farms in April 2015. 


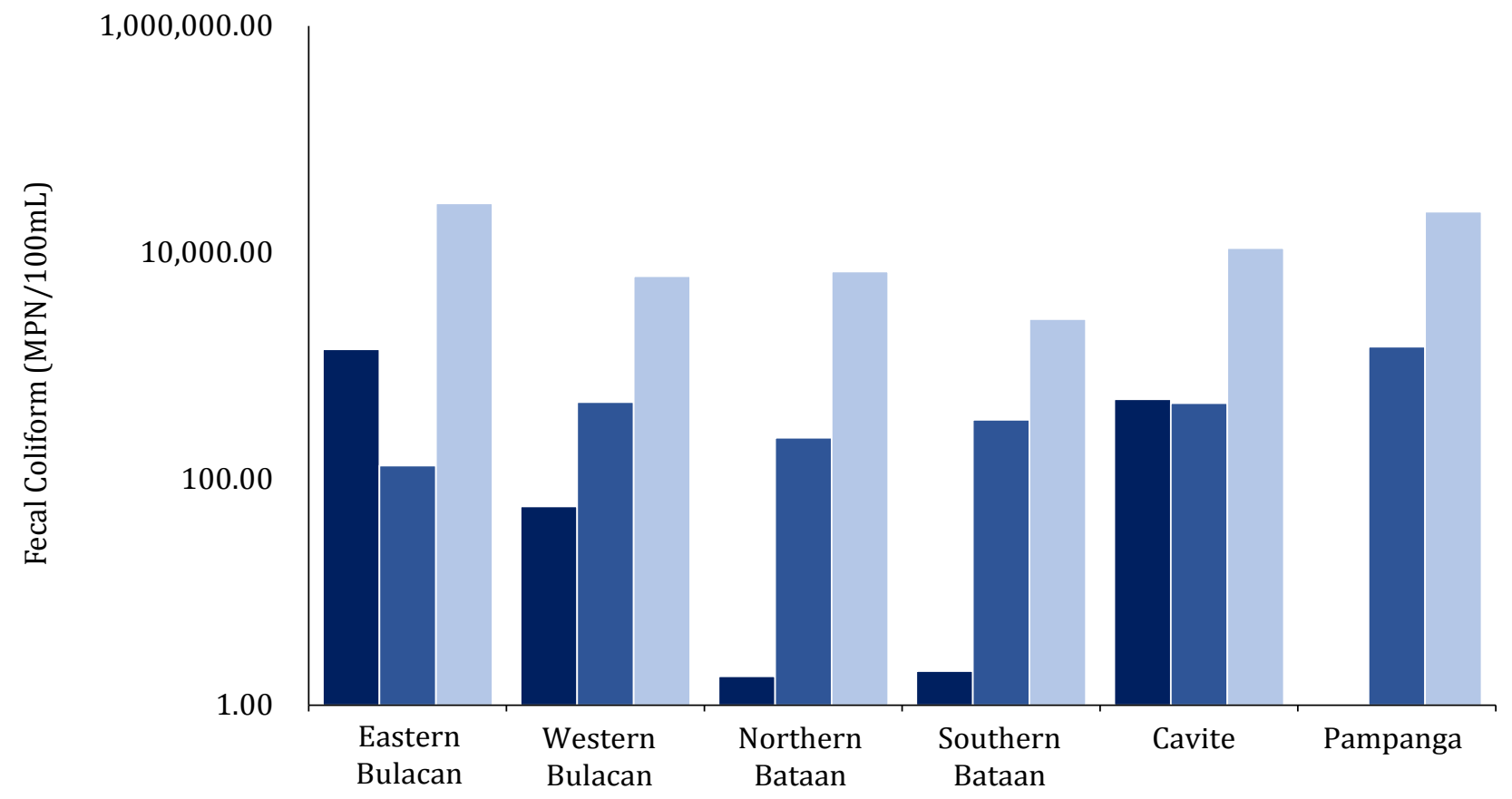

Figure 5.5. Fecal coliform levels in ponds, coastal areas, and river tributaries or water sources in February 2015. Pond Water Source

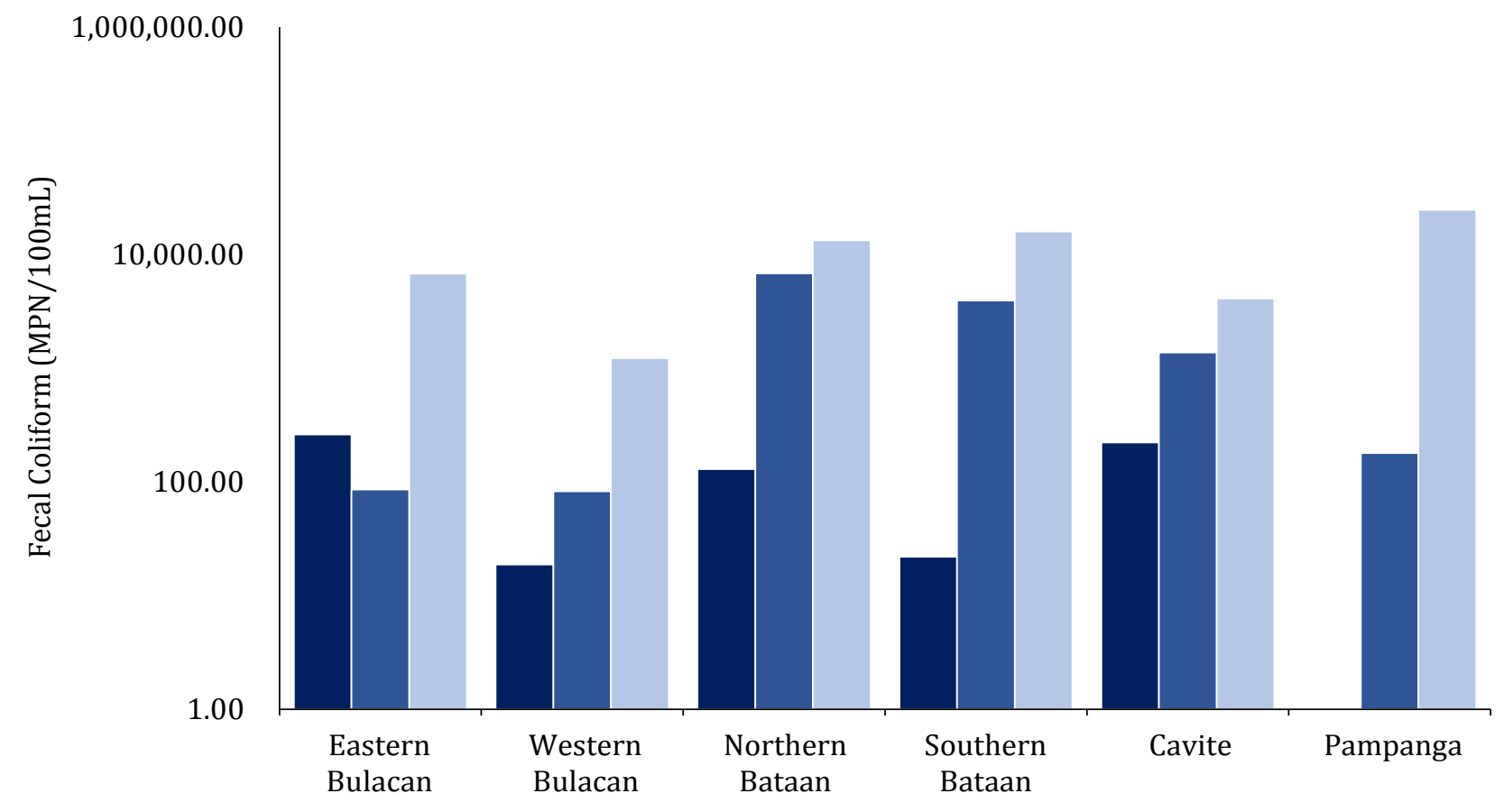

Figure 5.6. Fecal coliform levels in ponds, coastal areas, and river tributaries or water sources in April 2015. $\square$ Coastal Area $\square$ Pond $\square$ Water Source 
highest in Consuelo II, Pampanga and lowest in San Agustin, Western Bulacan. Those of this month were the highest $E$. coli levels among the sampling months. Of the blocks sampled, Southern Bataan had the lowest levels (average, $18 \mathrm{MPN} / 100 \mathrm{~mL}$ ) while Cavite had the highest (average, 8, $341 \mathrm{MPN} / 100 \mathrm{~mL}$ ).

The November 2014 E. coli concentrations ranged from $<1.8$ to $4,900 \mathrm{MPN} / 100 \mathrm{~mL}$, the highest recorded in Bangkal Sinubli, Pampanga and the lowest in Sta. Elena, Southern Bataan. Southern Bataan had the lowest (average, $58 \mathrm{MPN} / 100 \mathrm{~mL}$ ), while Pampanga had the highest (average, $772 \mathrm{MPN} / 100 \mathrm{~mL}$ ).

In February 2015, the range was $<1.8$ to 7, 900 MPN/100mL, highest in Sapang Kawayan, Pampanga and lowest in Tawiran, Eastern Bulacan, Samal (Coastal Area) and Ibaba, Northern Bataan, Camachile, Southern Bataan, and Consuelo II and San Antonio, Pampanga. E. coli levels during this month were the lowest among all the sampling periods. Western Bulacan (average, $12 \mathrm{MPN} / 100 \mathrm{~mL}$ ) had the lowest E. coli concentrations among the blocks, while Pampanga had the highest levels (average, 1, $489 \mathrm{MPN} / 100 \mathrm{~mL}$ ).

April 2015 E. coli levels ranged from $<1.8$ to 4, $700 \mathrm{MPN} / 100 \mathrm{~mL}$, lowest in Tawiran, Eastern Bulacan and Bangkal Pugad, Pampanga and highest in Capitangan, Northern Bataan. Lowest levels were observed in Western Bulacan (average, 40 MPN/100 mL), while highest were noted in Southern Bataan (average, $487 \mathrm{MPN} / 100 \mathrm{~mL}$ ).

Figures 5.8 and 5.9 show the E. coli concentrations of the ponds, coastal areas, and their river tributaries or water sources of all the blocks during the first and second replicates of the dry season (February and April 2015), respectively. It can be seen in the figures that E. coli concentrations in the water sources were consistently higher than those in ponds in all the blocks in February and April 2015. Comparison of the E. coli levels between the water sources and the ponds of the following areas showed that the former were significantly higher than the latter in February 2015: Eastern Bulacan, Western Bulacan, Northern Bataan, and Pampanga $(\mathrm{p}<0.01)$, and Southern Bataan $(p<0.05)$. In contrast, only Pampanga was found to have significantly higher $E$. coli level in the water source than the pond in April $2015(\mathrm{p}<0.05)$.

\section{Seasonal distribution of coliform bacteria in farmed fishery resources}

\section{E. coli IN FINFISH}

Results for the E. coli levels in the finfish samples collected are reflected in Figures 5.10, 5.11, 5.12, and 5.13.

E. coli concentrations in September and November 2015 ranged from $3 \mathrm{MPN} / \mathrm{g}$ to 75 $\mathrm{MPN} / \mathrm{g}$ with the highest recorded in milkfish sample collected from Batang 2, Pampanga (Fig. $5.10 \& 5.12$ ). Twelve out of 110 finfish samples or $10.91 \%$ exceeded the FDA Standard Limit for Fishes of $11 \mathrm{MPN} / \mathrm{g}$. Of the 70 milkfish samples collected, 8.57\% (all samples collected from Pampanga) failed to meet FDA Standard Limit, while 15\% (6/40) of the tilapia samples (both 2.5\% from Western Bulacan and Cavite, and 10\% from Pampanga) had E. coli levels greater than $11 \mathrm{MPN} / \mathrm{g}$.

On contrary, all milkfish samples collected in February and April 2015 conformed with the FDA Standard Limit for E. coli concentration in finfish of $11 \mathrm{MPN} / \mathrm{g}$, while $17.14 \%$ of the tilapia samples failed to meet FDA Standard Limit (Fig. 5.11 \& 5.13). E. coli levels during this sampling period ranged from $<3$ to $23 \mathrm{MPN} / g$, with the maximum value observed in tilapia samples collected from Batang 2 and Mani-ano, Pampanga. 


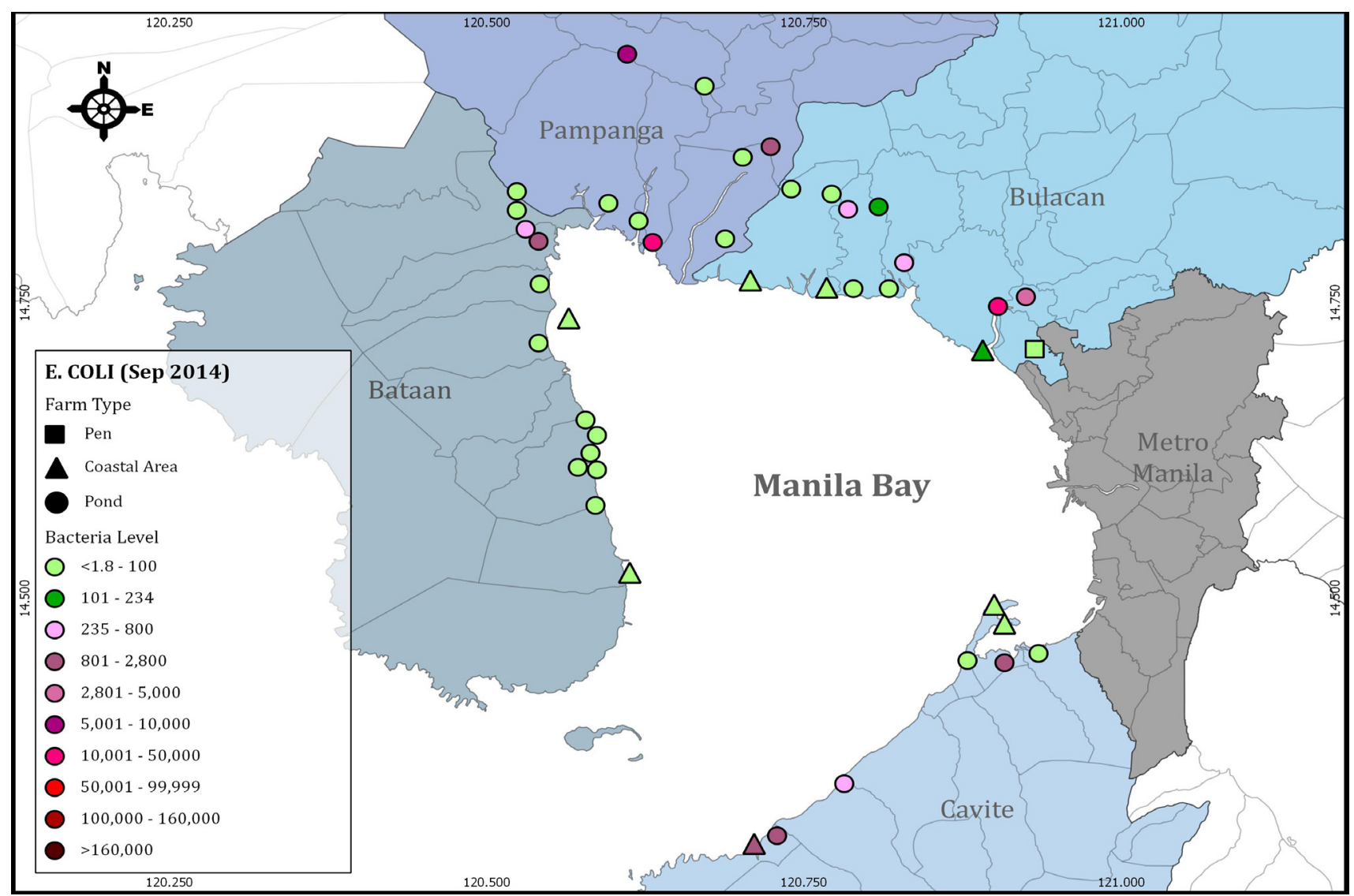

Figure 5.7a. E. coli levels in Manila Bay aquaculture farms in September 2014.

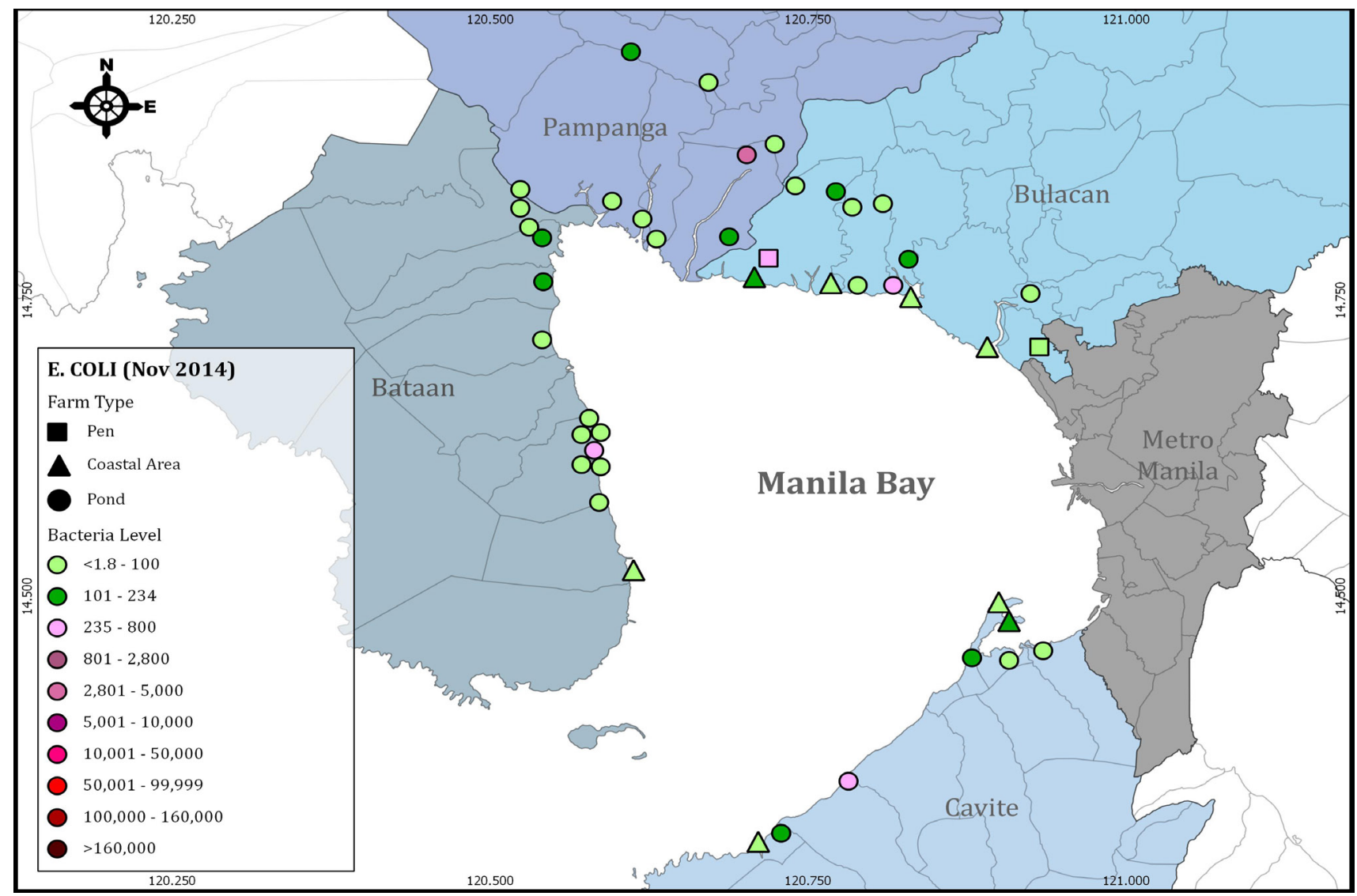

Figure 5.7b. E. coli levels in Manila Bay aquaculture farms in November 2014. 


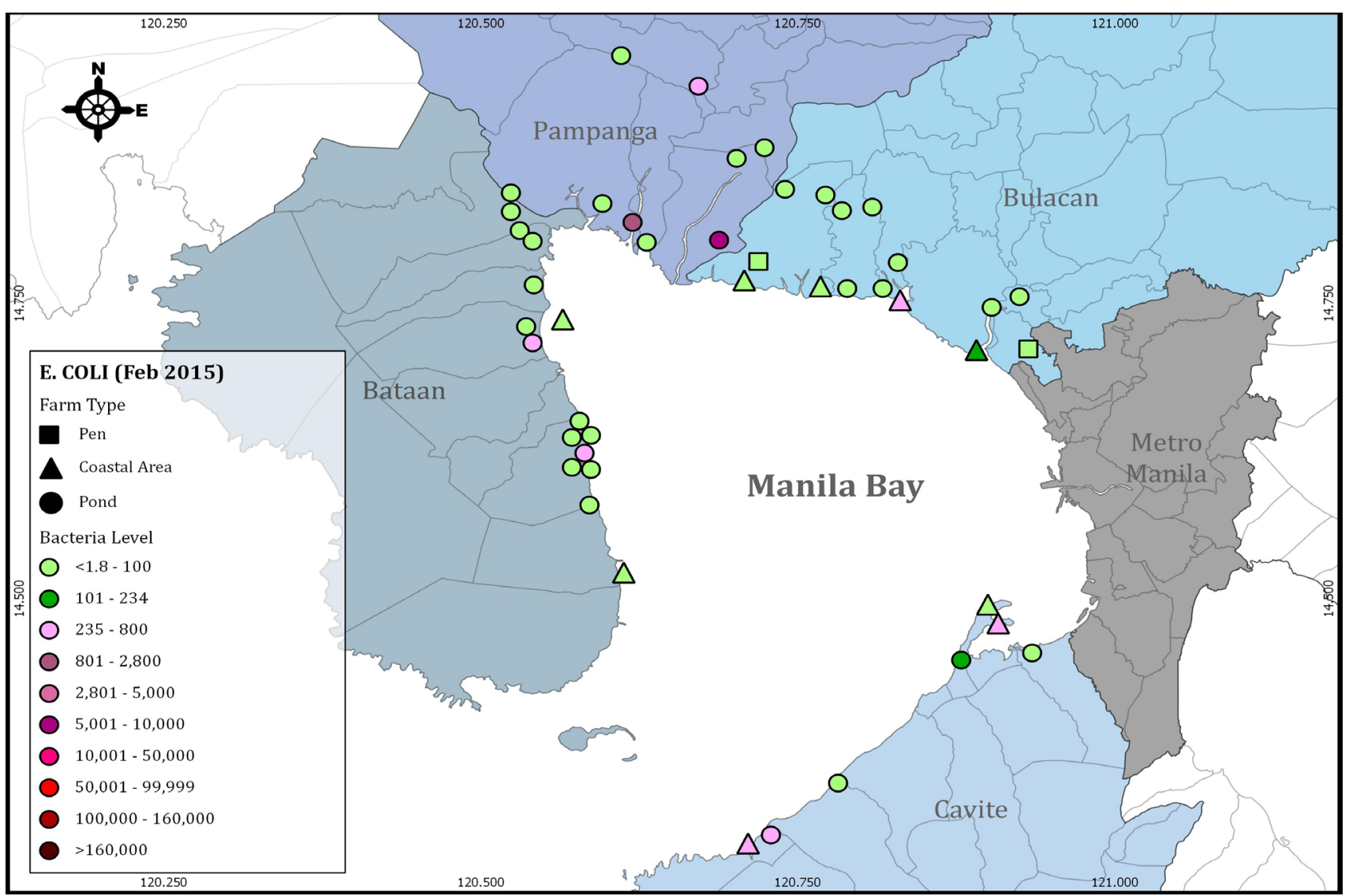

Figure 5.7c. E. coli levels in Manila Bay aquaculture farms in February 2015.

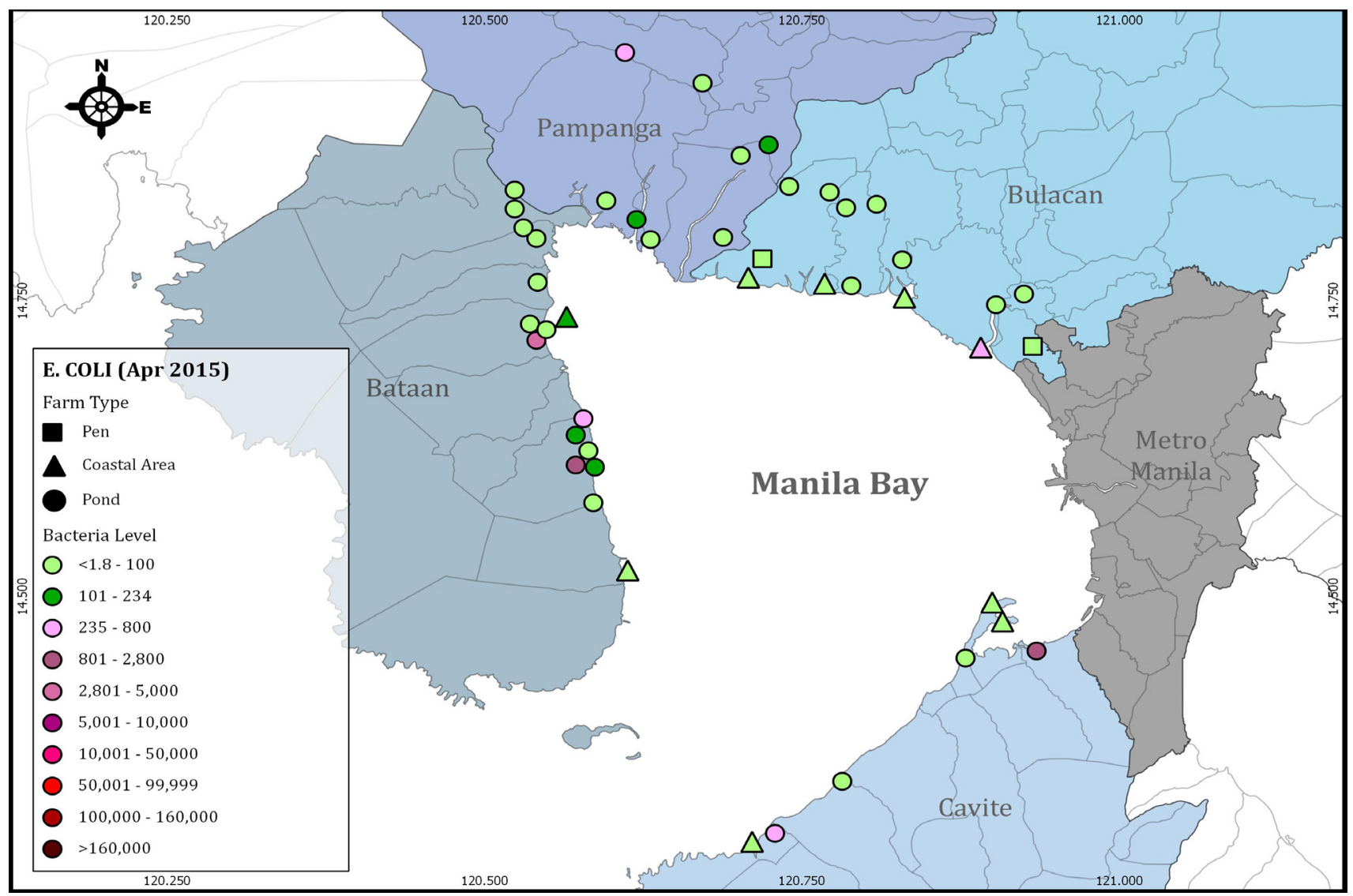

Figure 5.7d. E. coli levels in Manila Bay aquaculture farms in April 2015. 


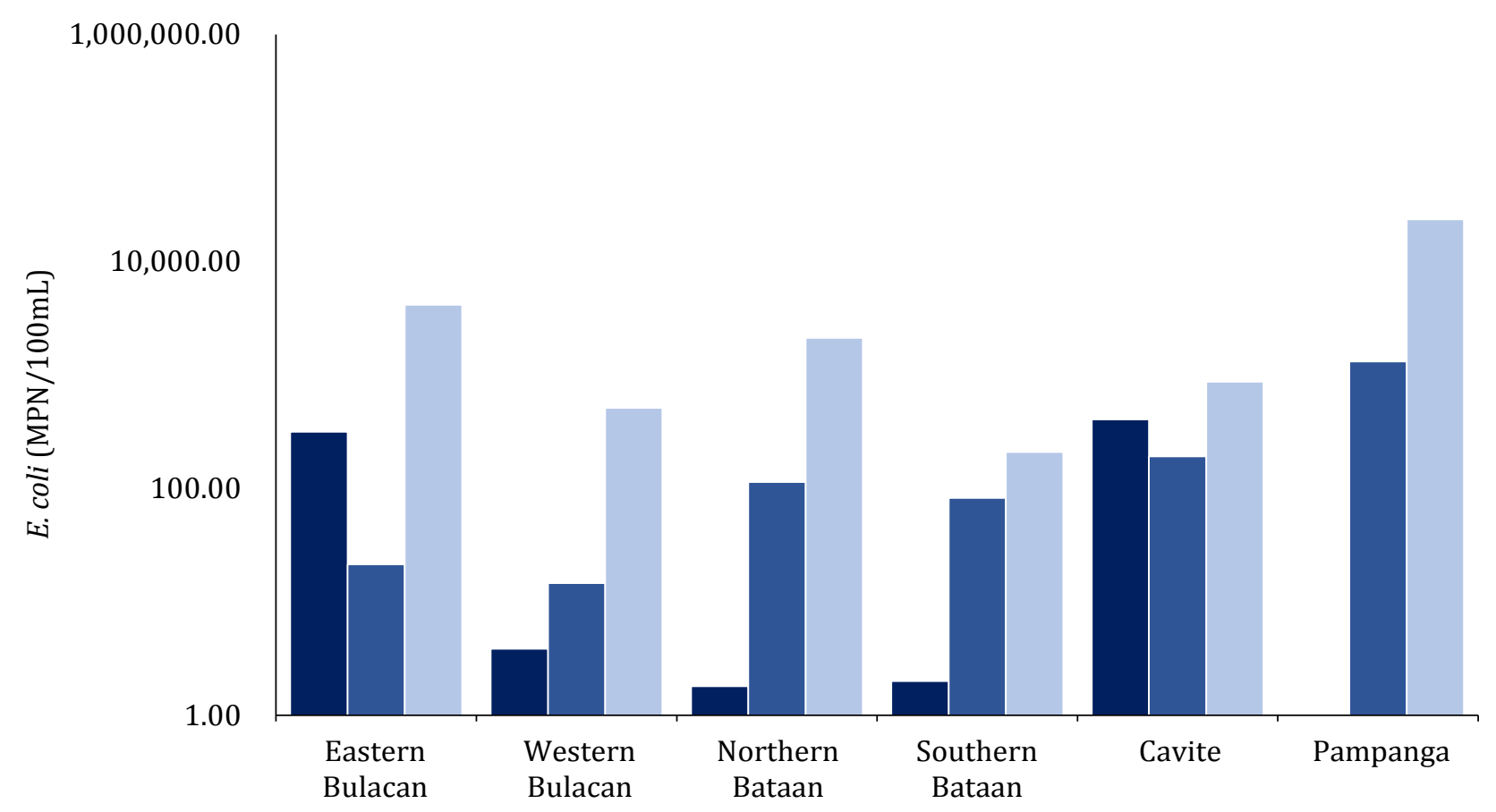

Figure 5.8. E. coli levels in ponds, coastal areas, and river tributaries or water sources in February 2015.

$\square$ Coastal Area $\square$ Pond $\square$ Water Source

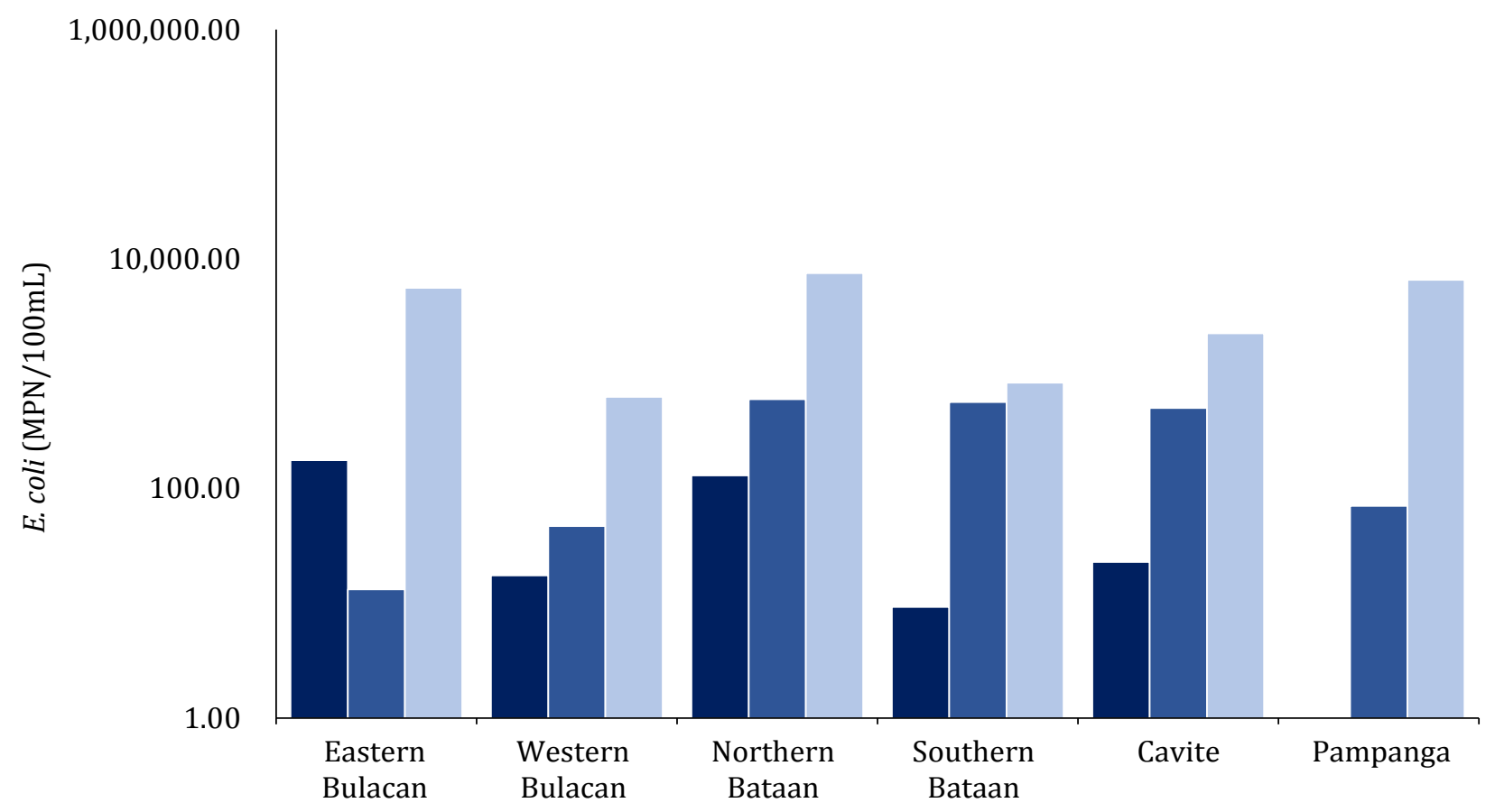

Figure 5.9. E. coli levels in ponds, coastal areas, and river tributaries or water sources in April 2015.

$\square$ Coastal Area $\square$ Pond $\square$ Water Source 


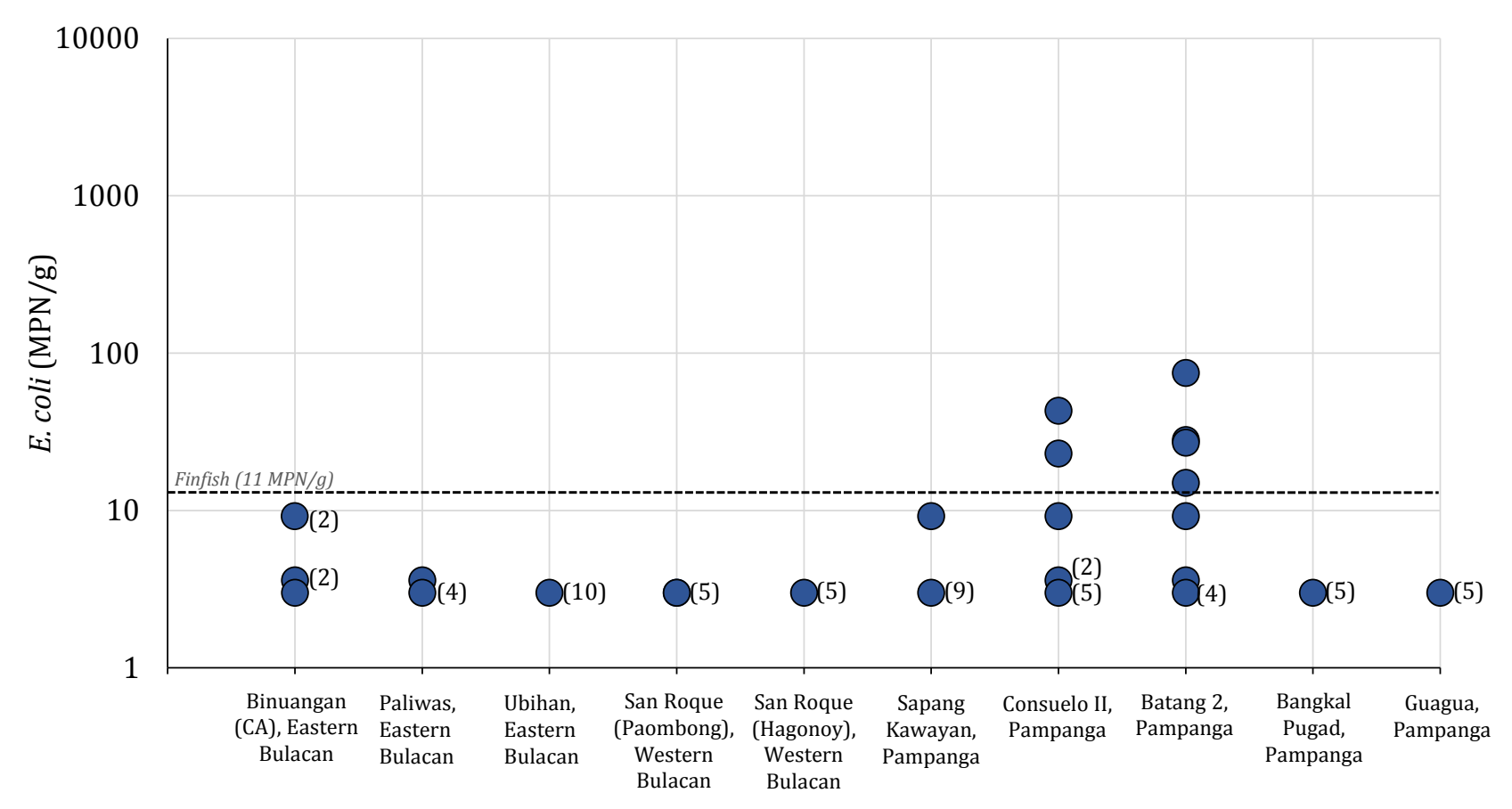

Figure 5.10. E. coli levels in milkfish samples collected from aquaculture farms along Manila Bay in September and November 2014.

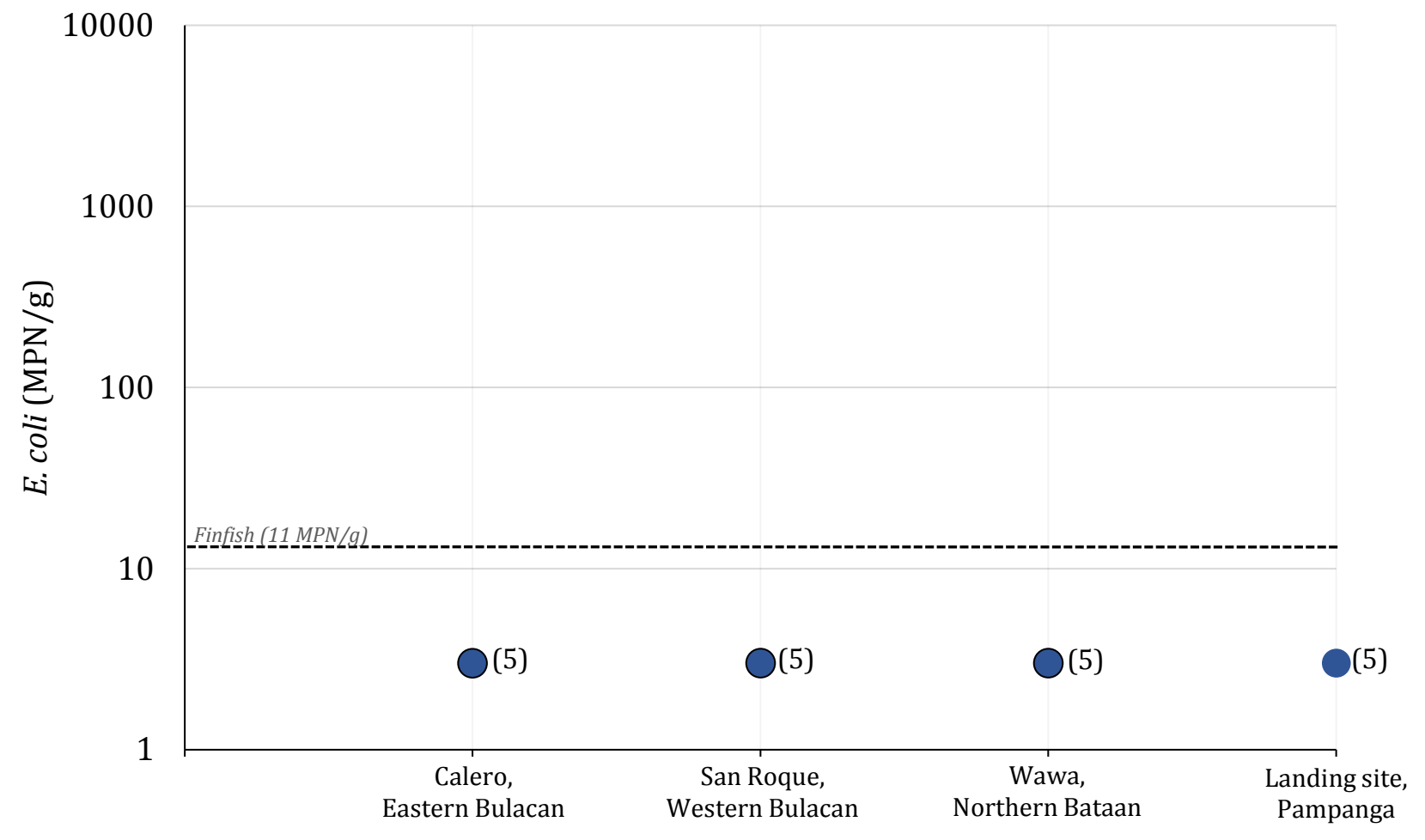

Figure 5.11. E. coli levels in milkfish samples collected from aquaculture farms along Manila Bay in February and April 2015.

\section{4}




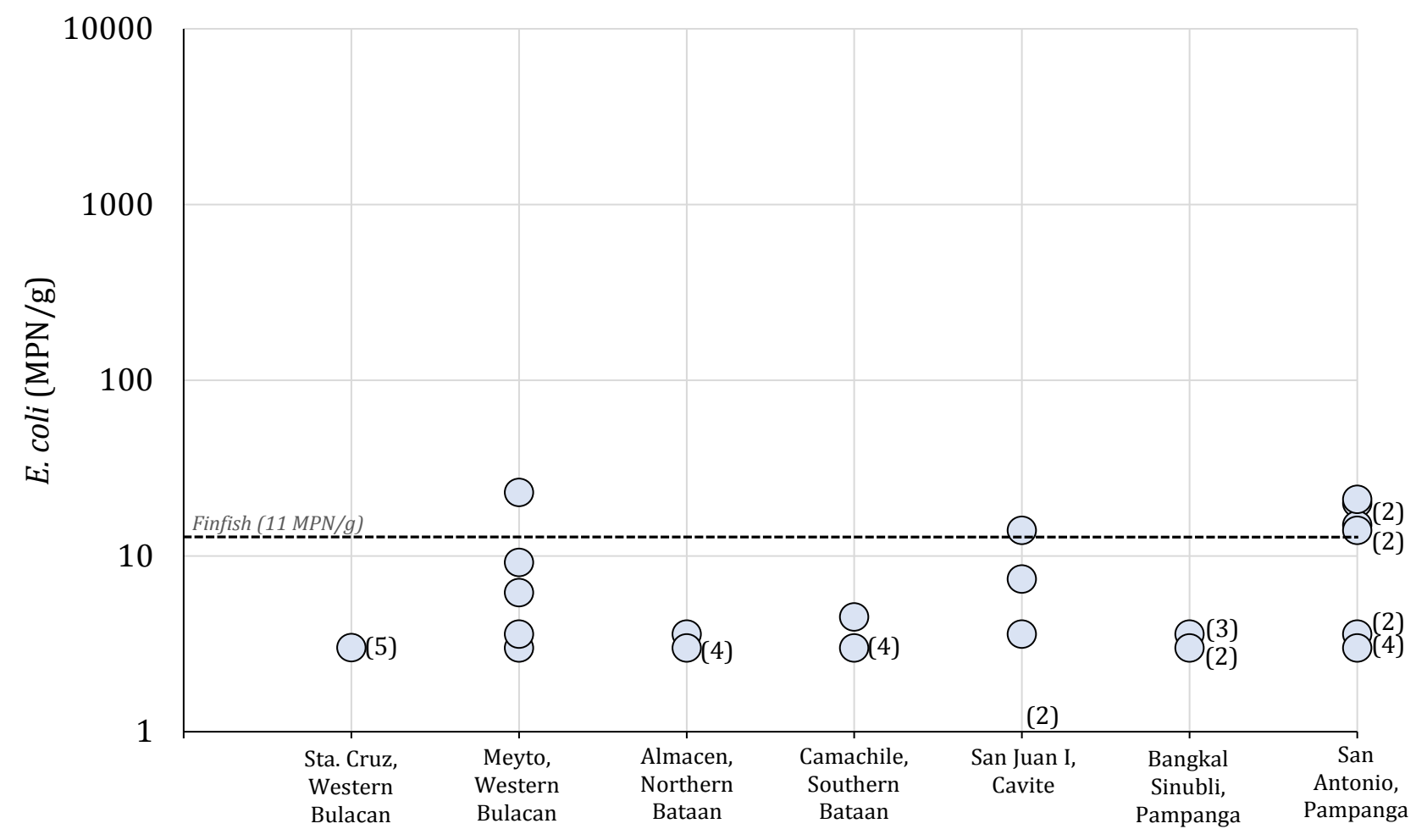

Figure 5.12. E. coli levels in tilapia samples collected from aquaculture farms along Manila Bay in September and November 2014.

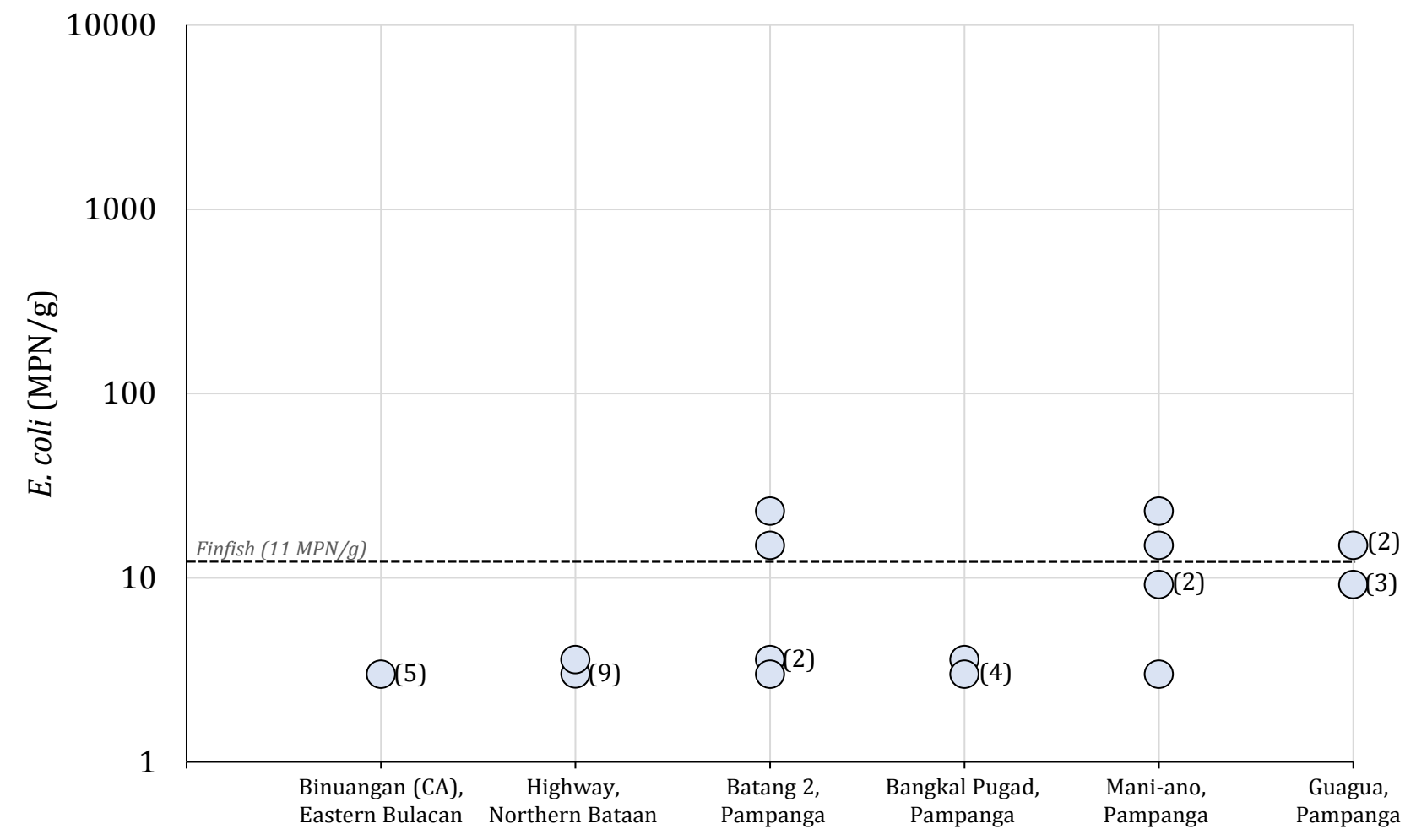

Figure 5.13. E. coli levels in tilapia samples collected from aquaculture farms along Manila Bay in February and April 2014. 


\section{E. coli IN CRUSTACEAN}

Results for the E. coli levels in the crustacean samples collected are reflected in Figures 5.14, 5.15, 5.16 and 5.17.

E. coli levels in September and November 2014 ranged from <3 MPN/g to $120 \mathrm{MPN} / \mathrm{g}$; the highest value noted in shrimp sample collected from Tawiran, Eastern Bulacan, where three out of five samples collected in the site failed to meet the FDA Standard Limit for $E$. coli concentration in crustaceans of $11 \mathrm{MPN} / \mathrm{g}$ (Fig. 5.14 \& 5.16). Out of the 40 samples collected, a total of 7 crustacean samples (17.5\%) - 4 shrimp and 3 crab samples - exceeded the FDA Standard Limit. Four out of $20(20 \%)$ shrimp samples - 15\% from Tawiran, Eastern Bulacan and 5\% from Consuelo II, Pampanga - failed to meet this limit, while only $15 \%$ of the crab samples (10\% from San Agustin and $5 \%$ from Sta. Cruz, both from Western Bulacan) had E. coli levels greater than $11 \mathrm{MPN} / \mathrm{g}$.

On the other hand, $28 \%$ of the shrimp samples in February and April 2015 failed to meet the FDA Standard Limit (8\% from Binuangan, Eastern Bulacan (CA) and $20 \%$ or $5 / 5$ from Bangkal Sinubli, Pampanga); while $4 \%$ of the crab samples (collected from Bangkal Sinubli, Pampanga) exceeded the standard (Fig. 5.15 \& 5.17). E. coli levels in February and April 2015 ranged from $<3 \mathrm{MPN} / \mathrm{g}$ to $240 \mathrm{MP}-$ $\mathrm{N} / \mathrm{g}$, with maximum value recorded in shrimp sample from Bangkal Sinubli, Pampanga.

\section{E. coli IN BIVALVES}

Results for the E. coli levels in the bivalve samples are reflected in Figures 5.18, $5.19,5.20$, and 5.21.

Of the 35 oyster samples collected in September and November 2014, four (11.43\%) exceeded the FDA Standard Limit for E. coli concentration in bivalves of $16 \mathrm{MPN} / \mathrm{g}$ (5.71\% from Pamarawan, Eastern Bulacan, 2.86\% in both Bacoor Bay and Bucana, Cavite) (Fig. 5.18 ). On the other hand, $15 \%$ of the mussel samples collected (all samples from Bacoor, Cavite) failed to meet the FDA Standard Limit for bivalves (Fig. 5.20). E. coli levels in the samples collected in September and November 2014 ranged from <3 MPN/g to 1, $100 \mathrm{MP}$ $\mathrm{N} / \mathrm{g}$ with the highest value observed in oyster samples collected from Pamarawan, Eastern Bulacan.

On the contrary, $17.5 \%$ of the oyster samples collected in February and April 2015 failed to meet FDA Standard Limit for bivalves of $16 \mathrm{MPN} / \mathrm{g}$ (12.5\% from Pamarawan, Eastern Bulacan and 5\% from Bucana, Cavite), while $30 \%$ of the mussel samples collected had E. coli levels greater than $16 \mathrm{MPN} / \mathrm{g}$ (5\% from Binuangan, Eastern Bulacan, 12.5\% from San Roque, Western Bulacan, 10\% from Samal, Northern Bataan, and 2.5\% from Bacoor Bay, Cavite (Fig. 5.19 \& 5.21). E. coli levels in the samples collected in February and April 2015 ranged from $<3 \mathrm{MPN} / \mathrm{g}$ to $1,100 \mathrm{MPN} / \mathrm{g}$ with the maximum value noted in oyster samples from Pamarawan, Eastern Bulacan where five out of five samples exceeded FDA Standard Limit for bivalves.

\section{Discussion}

Seasonal and spatial distribution of coliform bacteria in pond water and water sources

Several factors such as rainfall, population, livestock, pets, presence of waterfowls, and other aquaculture practices affect the concentration of these microorganisms (Oram, 2014).

Lower levels of total coliform, fecal coliform, and E. coli observed during the months of February and April 2015 (dry season) compared to September and November 2014 


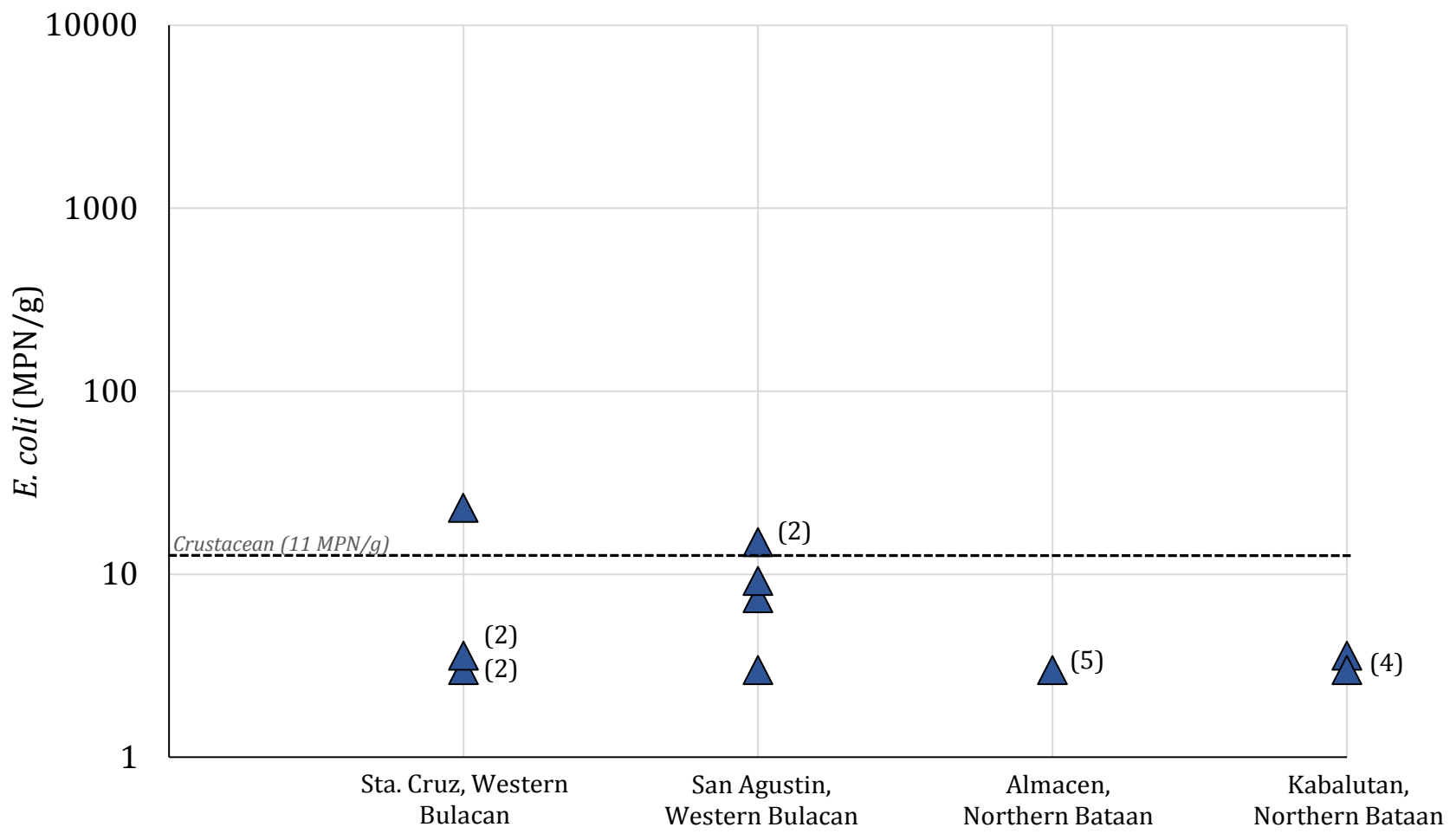

Figure 5.14. E. coli levels in crab samples collected from aquaculture farms along Manila Bay in September and November 2014.

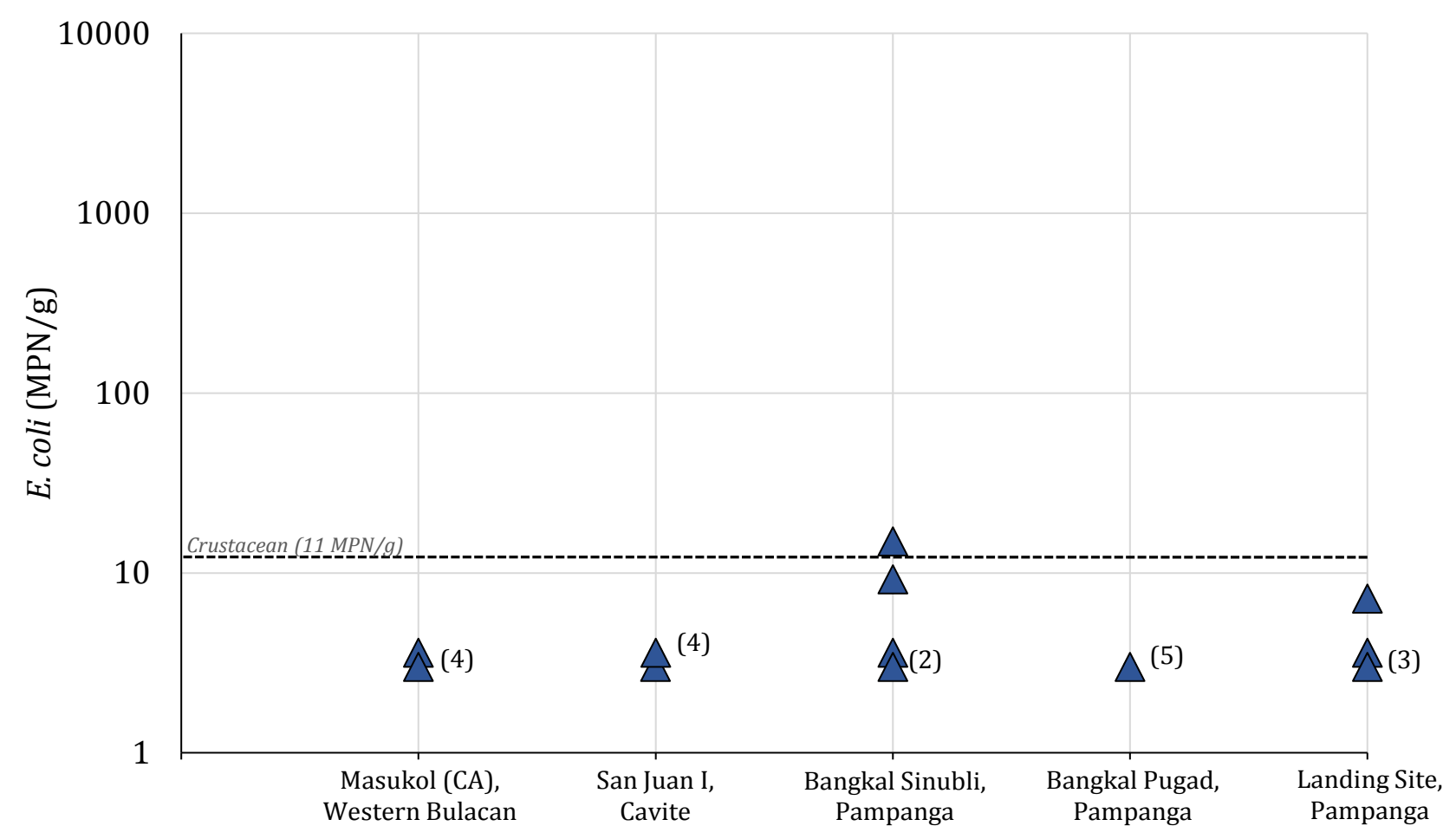

Figure 5.15. E. coli levels in crab samples collected from aquaculture farms along Manila Bay in February and April 2014. 


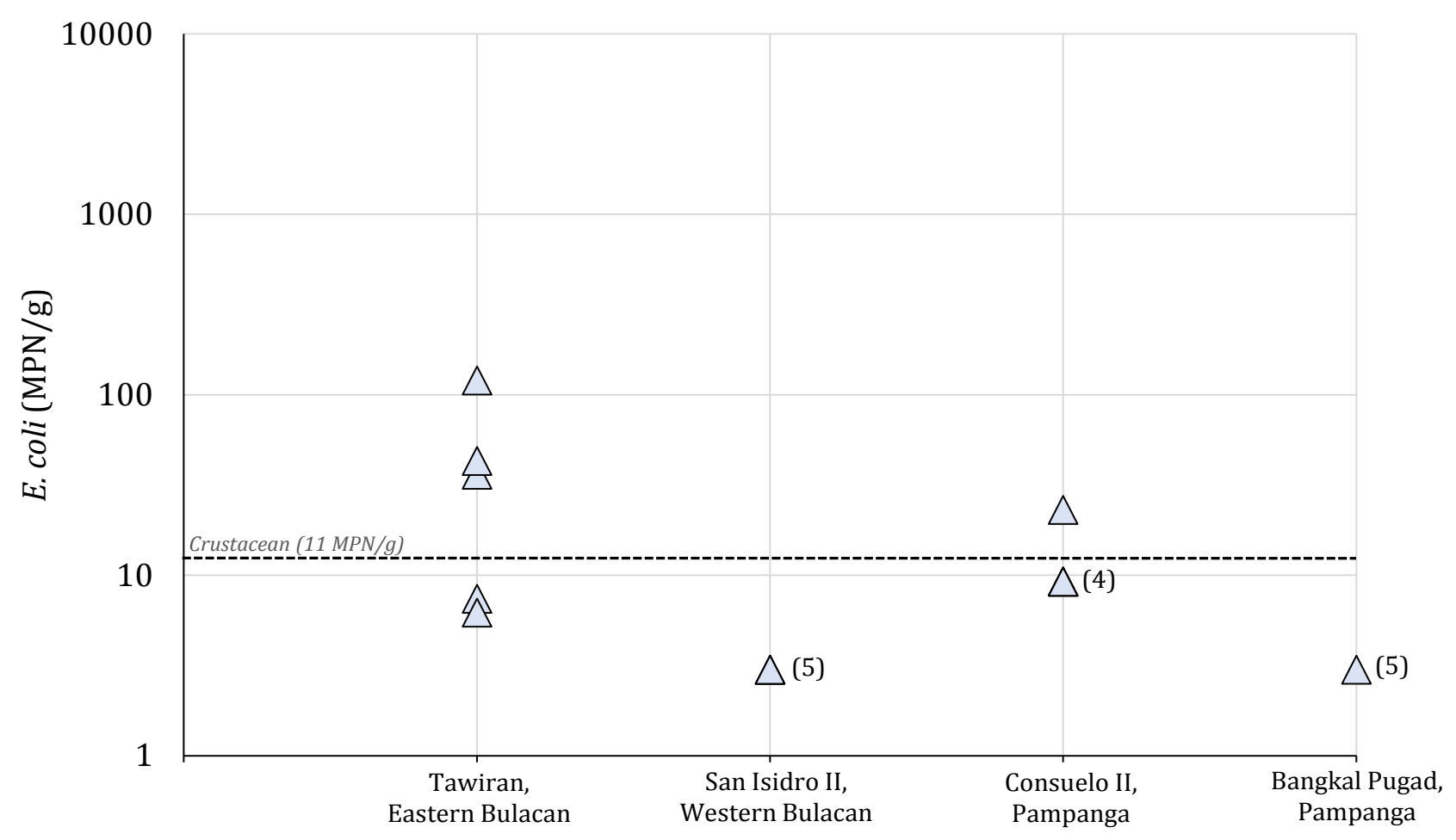

Figure 5.16. E. coli levels in shrimp samples collected from aquaculture farms along Manila Bay in September and November 2014.

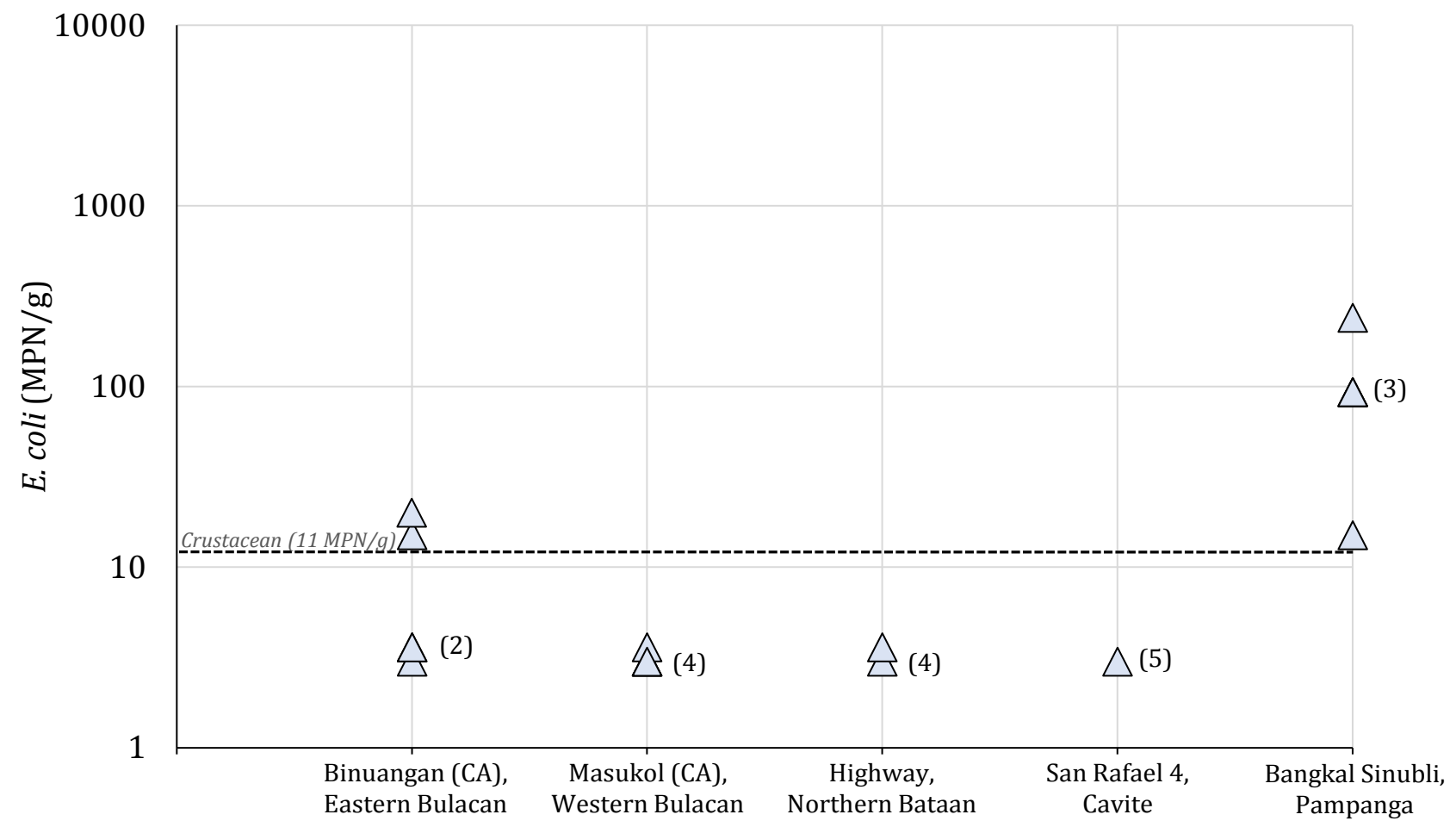

Figure 5.17. E. coli levels in shrimp samples collected from aquaculture farms along Manila Bay in February and April 2014. 


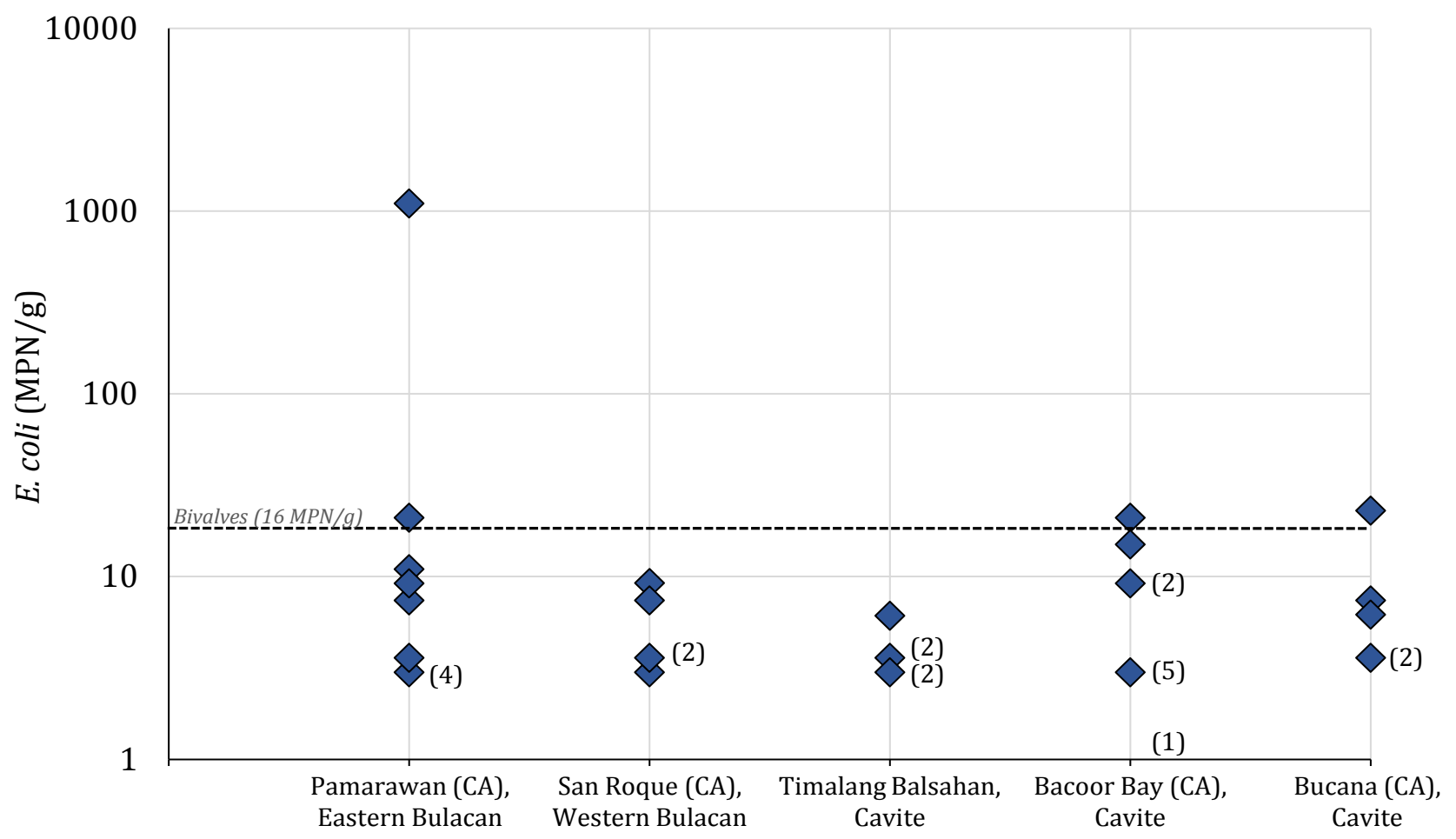

Figure 5.18. E. coli levels in oyster samples collected from aquaculture farms along Manila Bay in September and November 2014.

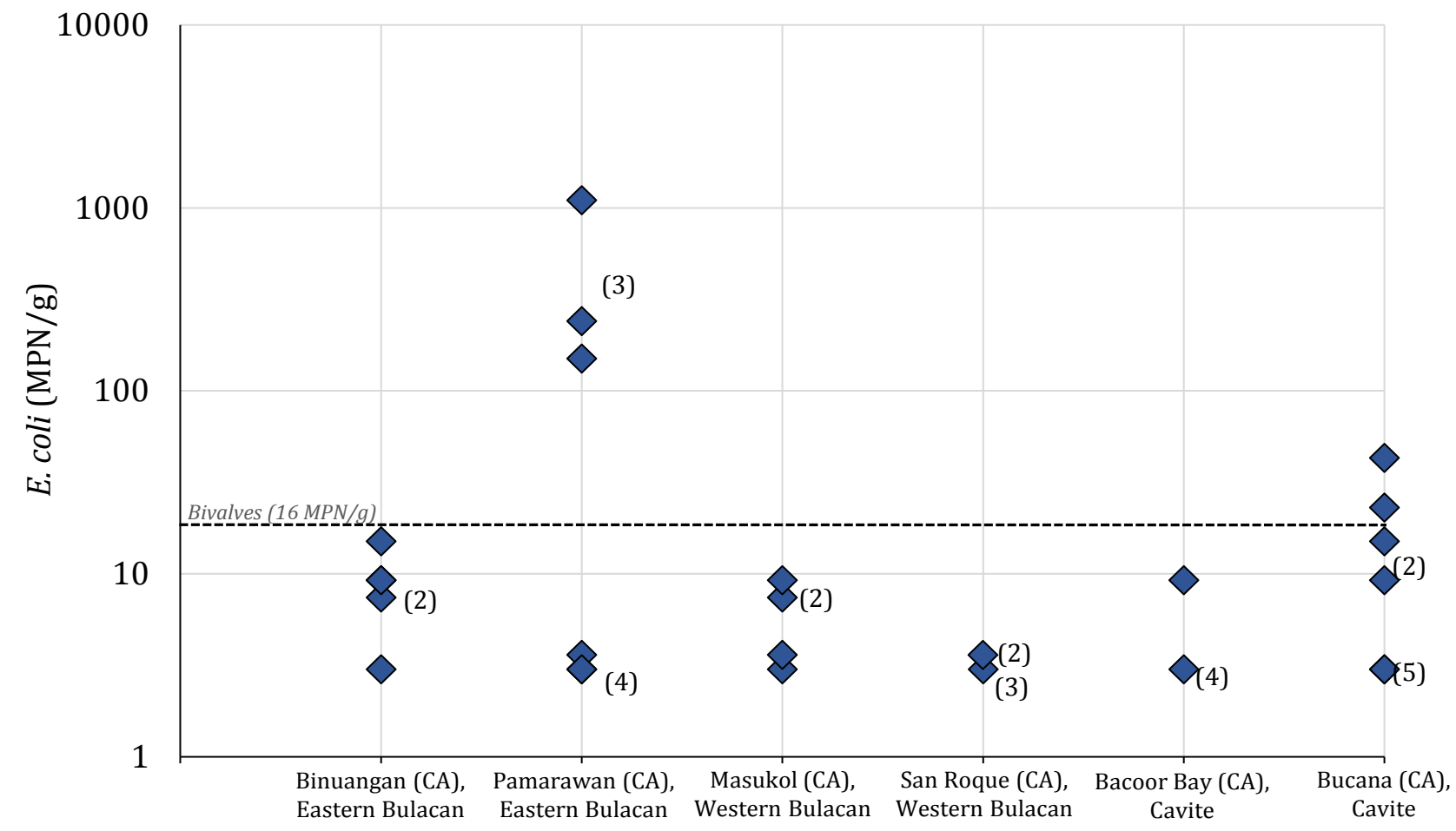

Figure 5.19. E. coli levels in oyster samples collected from aquaculture farms along Manila Bay in February and April 2014. 


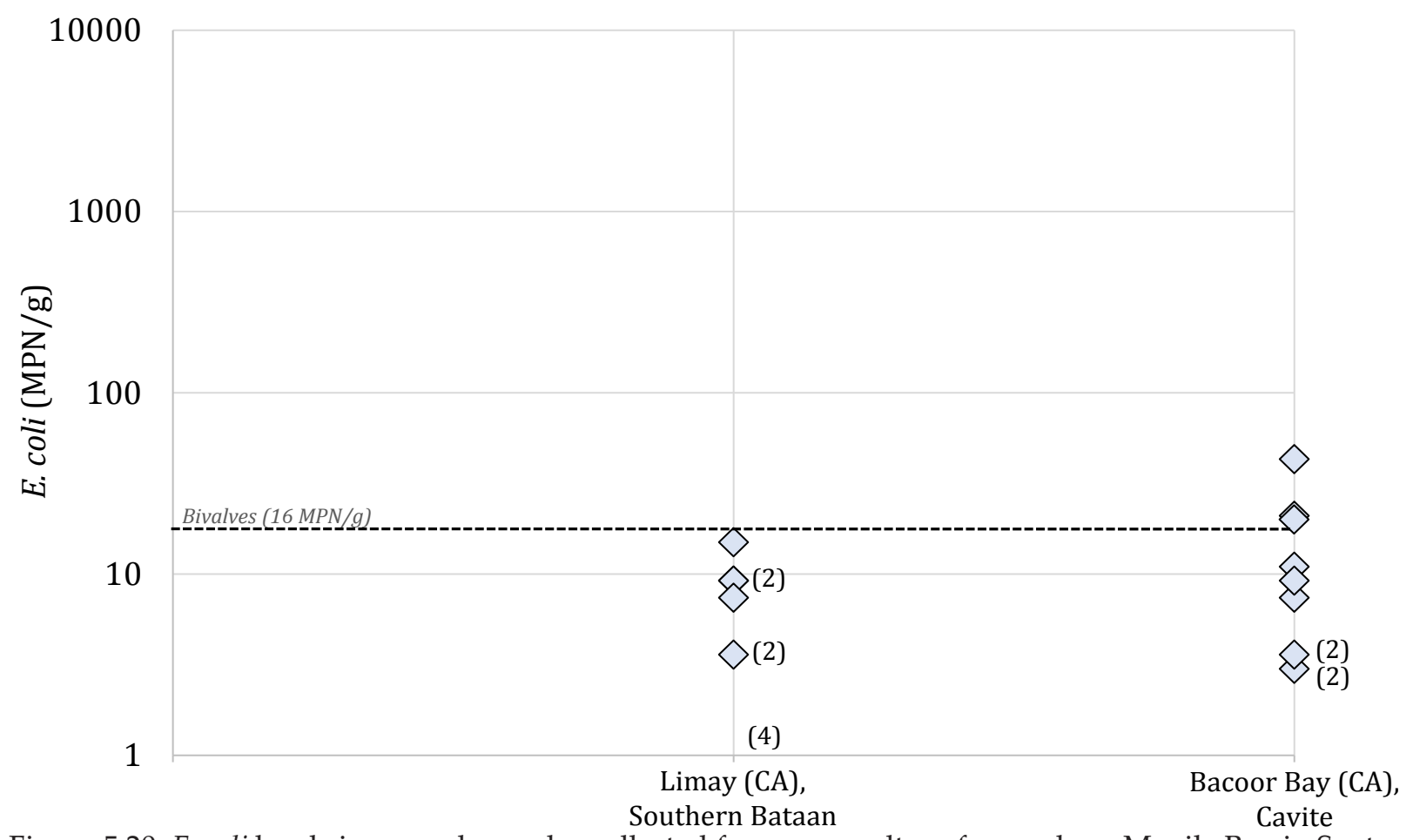

Figure 5.20. E. coli levels in mussel samples collected from aquaculture farms along Manila Bay in September and November 2014.

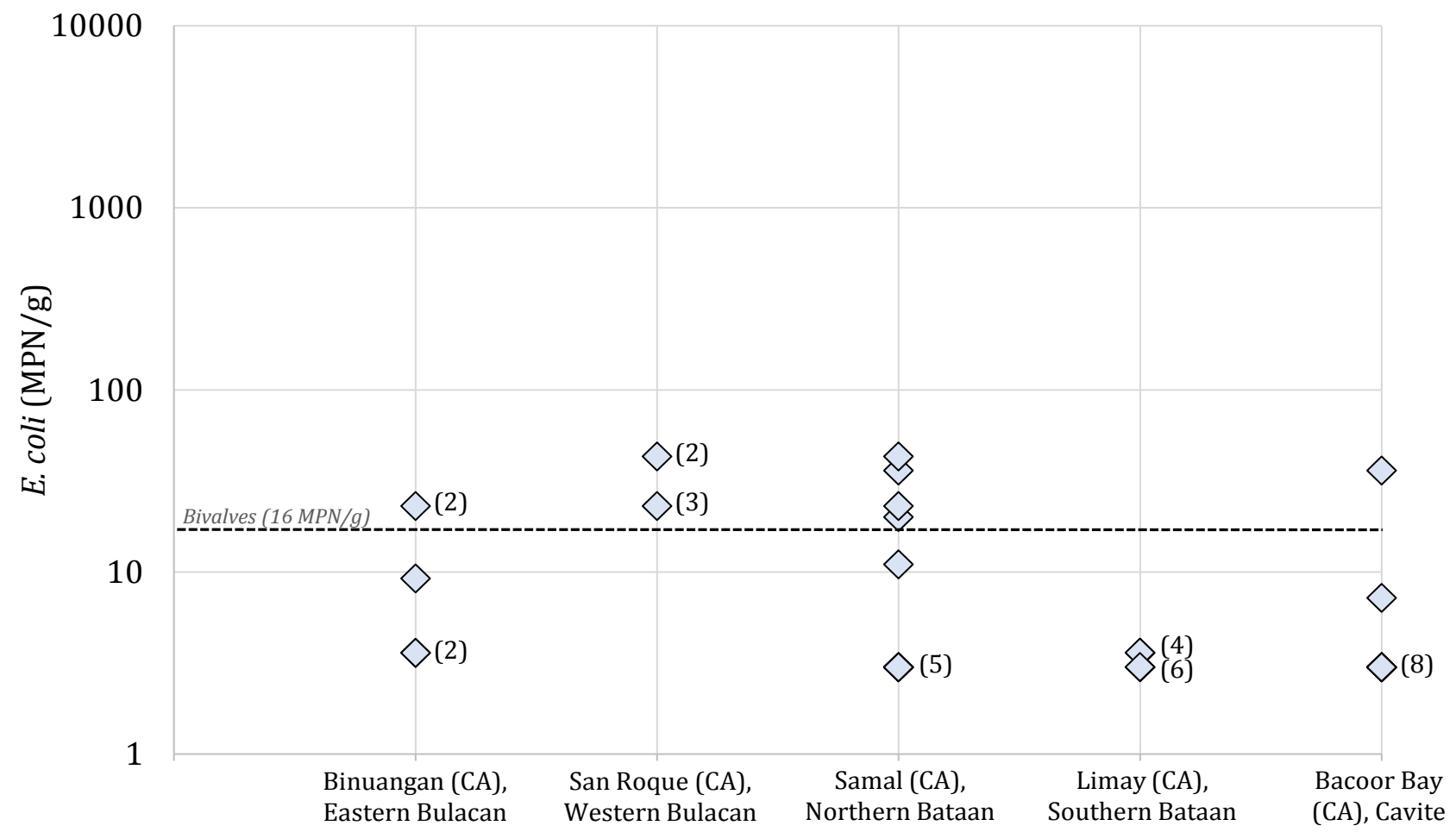

Figure 5.21. E. coli levels in mussel samples collected from aquaculture farms along Manila Bay in February and April 2014. 
(wet season) may be attributed to the differences in rainfall. Average rainfall in the sampled provinces during the wet season (233.5375) is 16.45 times greater than that of the dry season (13.5875). Rainfall causes nonpoint sources of pollution, like surface runoffs that carry contaminants, which include sediments, nutrients, bacteria from animal and human wastes, pesticides, metals, and petroleum by-products from the land (USGS, 2015; US EPA, 2016).

Although with some inconsistencies, data on livestock and poultry, pets, and waterfowls - presence and number - from a separate study on aquaculture activities and anthropogenic activities in the aquaculture farms simultaneously conducted by the team (Chapter 2)- associate with the data on the total coliform, fecal coliform, and E. coli levels in the aquaculture farms; sites with a relatively higher concentration of these microorganisms also had a relatively higher number of livestock and poultry, pets, and waterfowls. This may be due to the fact that total coliform, fecal coliform, and E. coli are found in the intestines and feces of warm-blooded animals, such as pets, livestock, poultry, wild animals, and humans (Washington State Department of Health, 2011; Meals et al, 2013).

It was also observed that aquaculture farms less than 10 meters from the residential area had relatively high coliform concentrations. The distance of the ponds to the residential areas might be a factor for the levels of microorganisms in the ponds since surface runoffs may collect contaminants from residential areas through faulty or not properly maintained septic tanks, pet droppings, and other wastes (Harvey, 2016).

Some of the aquaculture farms that performed liming, pond drying, removal of waste, and disinfection had relatively lower coliform concentrations compared to those that did not employ these activities. Aquaculture farms that used urea (46-0-0) and complete (14-14-14) fertilizers had relatively higher coliform levels compared to those that utilize chicken manure, which unexpectedly had relatively lower coliform concentrations. The increase in the available nutrients in the aquaculture farms owing to the application of fertilizers, may have favored the growth of bacteria. This is supported by the studies of Baluyut (1989) and Stander (2012) where they had mentioned that liming, pond drying, removal of waste, and disinfection eradicated unwanted or wild species along with undesirable microorganisms, while fertilization stimulated and maintained growth of natural food.

Among the aquaculture farms that administered the following feeding materials: lablab, lumot, low value feed, commercial feed, bread, and surface plankton; those that utilize natural food - lablab and lumot - had a lower coliform bacterial content as compared to those that utilized bread. This maybe because the broadcasting of bread in the pond attracts wild bird species and water fowls; and where waterfowls and birds flock, fecal coliform counts can surge. Data on the use of low value feed, commercial feed, and surface plankton did not correlate with the data on the coliform levels in the ponds.

As can be observed in the maps, highest total coliform, fecal coliform, and E. coli levels in the aquaculture farms and coastal areas were noted mostly in Pampanga and Cavite. This may be caused by the differences in the spatial segregation of the blocks. Pampanga River, the major river system of the Pampanga province, had failed the standards for DO and BOD of $5 \mathrm{mg} / \mathrm{L}$ and $10 \mathrm{mg} / \mathrm{L}$, respectively, in all sampling stations as reported in the Manila Bay Atlas in 2007. Dissolved oxygen (DO) is oxygen dissolved in water. It is necessary 
for the sustenance of fish life and other aquatic organisms. Low DO suggests incapacity to harbor life (Lee, 2005). On the other hand, BOD or biological oxygen demand represents the amount of oxygen $(\mathrm{mg} / \mathrm{L})$ needed by bacteria and other microorganisms to oxidize organic matter in an area; higher BOD means lower available oxygen for aquatic organisms (Palanna, 2009). The Angat River, which passes through NCR merges with the Pampanga River before discharging into the bay. This means that possible pollutants picked up by the Angat River will add to what is already present in the Pampanga River. Furthermore, upland Pampanga has the highest agricultural and fishpond areas. Agriculture runoff is considered a non-point source of pollution and a major contributor of contamination (US EPA, 2012).

It is interesting that Cavite, which is located south of Manila Bay where the bay connects to the sea and contamination is supposedly minimal, was observed to have the highest bacterial levels. This may be attributed to the fact that Cavite has the highest population and most built-up areas among the coastal provinces of the bay (PSA, 2010; Manila Bay Atlas, 2007). The increasing population and urbanization in the province increases the nonpoint sources of pollution such as urban runoffs, which are usually contaminated with organic matter and bacteria, among other pollutants. In addition, urbanization also increases combined sewer flow, which may also cause contamination (US EPA, 1980).

\section{Seasonal distribution of coliform bacteria in} farmed fishery resources

E. coli levels in farmed fishery resources were higher during the dry season, with the exception of crab and milkfish. Escherichia coli is a typical mesophile, which grows optimally at $39^{\circ} \mathrm{C}$ with a minimum of $8^{\circ} \mathrm{C}$ and a maximum of $40^{\circ}$ (Madigan et al, 2012). This suggests that as the temperature increases, growth of E. coli is favored.

The decrease in the E. coli levels in crab and milkfish samples during the dry season may be attributed to the E. coli levels in the water column. Fish, being cold-blooded animals, cannot be a natural host to E. coli, as mentioned in the study of Apun et.al. (as cited in Barbosa et al, 2104). It only acquires the microorganisms when ingesting food contaminated with fecal matter and/or presence of E. coli in the water, which may enter the fish through ingestion and penetration through lacerations (Zhuikov, 2008; Missouri Department of Natural Resources, 2014). This means that Escherichia coli level in fishery commodities is associated to the E. coli level in the water medium; higher E. coli concentration in the water may result in higher $E$. coli concentrations in the fishery commodities and vice versa.

However, some aquaculture species do not have the ability to regulate their body temperature and are easily influenced by the temperature around them (Fishresearch.org, 2009). This means that as the temperature of the medium increases, the temperature of their body also increases, which in turn causes an increase in their E. coli levels during warmer temperatures (dry season) as was demonstrated by the increase in the number of samples that failed to meet the standard limits during the dry season.

\section{Conclusion}

Total coliform, fecal coliform, and E. coli in water tended to increase in the wet season, their approximate average concentrations during the study being 8,747 MPN/100mL, 2,808 MPN/100mL, and 1,216 MPN/100mL, respectively. Those in the dry were lower at 
around 6,255 MPN/100mL, 1,223 MP$\mathrm{N} / 100 \mathrm{~mL}$, and $286 \mathrm{MPN} / 100 \mathrm{~mL}$, respectively. More water samples tended to exceed the DENR Standard Limit for Total Coliform of $5,000 \mathrm{MPN} / 100 \mathrm{~mL}$ in the wet season than in the dry season (roughly 25 vs. 10\%). Farmed fishery resources, on the other hand, were more contaminated in the dry season favored by the warmer temperature. The following are the rough percentages of exceedance of the FDA standard limits in decreasing order: $25 \%$ of the mussel samples, $24 \%$ of shrimp, $16 \%$ of tilapia, $14.67 \%$ of oyster, $8.89 \%$ of crab, and $6.6 \%$ of the milkfish.

\section{RefERenCeS}

American Public Health Association (APHA), American Water Works Association (AWWA), Water Environment Federation (WEF). (1999). Standard Methods for the Examination of Water and Wastewater, Multiple-tube Fermentation Technique for Members of the Coliform Group. Retrieved from http://www.mwa.co.th/download/ file_upload/SMWW_9000-10900a.pdf.

Auburn University and USDA/Natural Resources Conservation Service. Pond fertilization, Alabama Aquaculture: Best Management Practice, BMP No. 8. Retrieved February 26, 2016. Retrieved from http://www.aces.edu/dept/fish eries/aquaculture/pdf/G08Fertiliza tionofPonds.

Bacteriological Analytical Manual, BAM (8th Ed, Revision A). (2002). Chapter 4: Escherichia coli and coliform bacteria: Conventional method. Retrieved from http://www.fda.gov/Food/Food ScienceResearch/LaboratoryMethods/ ucm064948.htm.
Baluyut, E.A. (1989). Aquaculture systems and practices: A selected review. Retrieved 15 January 2016. Re trieved from http://www.fao.org.

Barbosa, M.M.C., Pinto, F.R., Ribeiro, L.F., Guriz, C.S.L., Ferraudo, A.S., Maluta, R.P., Rigobelo, E.C., Avila, F.A., \& Amaral, L.A. (2014). Serology and patterns of antimicrobial susceptibility in Escherichia coli isolates from pay-to-fish

ponds. Arquivos do Instituto Biológico, 81(1), 43-48. doi: 10.1590/ S1808-16572014000100008.

Bocek, A. (ed). Water harvesting and aquaculture for rural development: Chemical fertilizers for fish ponds, International Center for Aquaculture and Aquatic Environments. Retrieved February 26, 2016. Retrieved from http:// www.ag.auburn.edu.

Centers for Disease Control and Prevention (2015). E. coli (Escherichia coli). Retrieved March 29, 2016. Retrieved from http://www.cdc.gov.

DENR Administrative Order No. 34. Series of 1990. (1990). Revised water usage and classification/water quality criteria amending sections nos. 68 and 69, Chapter III of the 1978 NPCC rules and regulation. Retrieved from http://emb. gov.ph/wp-content/uploads/2016/04/ DAO-1990-34.pdf.

DepartmentofAgriculture-Bureau of Fisheries and Aquatic Resources. (2011). Philippine fisheries profile 2011. Retrieved online from http://www.bfar.gov.ph.

Food and Drugs Administration. (2013). Revised guidelines for the assessment of microbiological quality of processed 
foods. FDA Circular No. 2013-010. Retrieved fromwww.fda.gov.ph/attach ments/article/17218/FC2013-010.pdf.

Food and Drugs Administration, FDA. (2014). Evaluation and definition of potentially hazardous foods: Chapter 4 Analysis of microbial hazards related to timeltemperature control of foods for safety. Retrieved from http://www. fda.gov/Food/FoodScienceResearch/ SafePracticesforFoodProcesses/ucm 094147.htm

Forsythe, S.J. (2010). The microbiology of safe food: Food science and technology (2nd Ed.). United Kingdom: John Wiley \& Sons, pp. 461.

Harvey, J.K. (2016). Pollution sources: Point and nonpoint. In Water Encyclopedia: Science and Issues. Retrieved from http://www.waterencyclopedia.com/ Po-Re/Pollution-Sources-Point-andNonpoint.html.

Hayhurst, C. (2004). E. coli: Epidemics series (1st Ed.). New York: The Rosenburg Publishing Group, Inc, pp. 64.

Henze, M., van Loosdrecht, M.C.M., Ekama, G.A., \& Brdjanovic, D. (2008). Biological wastewater treatment: Principles, modelling and design. United Kingdom: IWA Publishing, pp. 511.

International Commission on Microbiological Specifications for Foods (ICMSF). (1986). Sampling plans for fish and shellfish. In Microorganisms in Foods 2, Sampling for Microbiological Analysis:Principles and Specific Applications (2nd Ed.) (pp. 181-193). Blackwell Scientific Publications. Retrieved from http://www.icmsf.org/pdf/icms f2.pdf.
Lee, C.C. (2005). Environmental engineering dictionary (4th Ed.). United States of America: Government Institutes, pp. 941.

Madigan, M.T., Martinko, J.M., Stahl, D.A., \& Clark, D.P. (2012). Brock Biology of Microorganisms (13th Ed.). USA: Pearson Education, Inc., pp. 1152 .

Manila Bay Atlas (2007). Manila bay area: Environmental Atlas. Philippines: PEMSEA. pp. 204.

Meals, D.W., Harcum, J.B., \& Dressing, S.A. (2013). Monitoring for microbial pathogens and indicators, Tech Notes, 9. Retrieved 15 January 2016. Retrieved from http://www.bae.ncsu.edu.

Microbiology Society (2016). Microbes of the human body: Routes of transmission, Microbiology Online. Retrieved 04 March 2016. Retrieved from http:// www.microbiologyonline.org.uk.

Missouri Department of Natural Resources (2014). E. coli: General information, Water Protection Program Fact Sheet, 2401. Retrieved 08 April 2016. Retrieved from http://www.dnr.mo.gov.

Nataro, J.P., \& Kaper, J.B. (1998). Diarrheagenic Escherichia coli. Clinical $\mathrm{Mi}$ crobiology Reviews, 11(1), 142-201. American Society for Microbiology. doi: 0893-8512/98\$04.00+0

Oram, B. (2014). E. coli in Water, Water Research Center. Retrieved 15 January 2016. Retrieved from http://www. wa ter-research.net.

Palanna, O.G. (2009). Engineering chemistry. New Delhi: Tata McGraw Hill Education Pvt. Ltd., pp. 623. 
Parco, G.F. (2014). Manila bay integrated water quality management project. Retrieved 15 January 2016, from http:// www.pemsea.orgs.

PEMSEA. (2006). Initial valuation of selected uses and habitats and damage assessment of Manila Bay: PEMSEA technical information report no. 2006/01. Quezon City, Philippines: Global Environment Facility/United Nations Development Programme/International Maritime Organization Regional Programme on Building Partnerships in Environmental Management for the Seas of East Asia (GEF/UNDP/PEM SEA), pp. 165.

PEAMSEA. (2006). Sustainable development and management of Manila Bay: A focus on water quality. Policy Brief, 2 (2), 1-7.

Perez, R. T., Amadore, L. A., \& Feir, R. B. (1999). Climate change impacts and responses in the Philippines coastal sector. Climate Research, 12, 97-107.

Philippine Statistics Authority (PSA). (2010). 2010 Census of Population and housing. Philippines: PSA.

PHILMINAQ. (2008). Mitigating impact from aquaculture in the Philippines: 6th Framework Programme, pp. 97. Retrieved from http:/cordis.europa.eu/ docs/publications /1228/122807451-6_ en.pdf.

Sea surface temperature: Water temperature is an important factor in the environment of fish. (2009). Retrieved March 7, 2016, from http://www.fishresearch. org/sea-surface-temperature.

Snyder, P. (2008). Characteristics of Esche- richia coli, 1908, Section-2-1908-10-05. Retrieved March 2016, from http:// www.hi-tm.com/1908/?C=N;O=D.

Stander, H. Pond preparation for semi-inten sive fish culture. Retrieved 26 February 2016. Retrieved from http://www0. sun.ac.za/aquaculture/uploads/arti cles.

Treyens, C. (2009). Bacteria and private wells - Information every well owner should know. On Tap Magazine Winter 2009, 19-22. Retrieved 18 January 2016. Retrieved from http://www.nesc.wvu. edu.

United States Environmental Protection Agency (US EPA). (2012). Agriculture: Surface and Ground Water. Retrieved from http://www.epa.gov.

United States Environmental Protection Agency (US EPA). (2012). Water: Monitoring and Assessment. Retrieved from http://www.epa.gov.

United States Environmental Protection Agency (US EPA). (2013). Revised Total Coliform Rule and Total Coliform Rule. Retrieved from https://www. epa.gov/dwreginfo/revised-total-coli form-rule-and-total-coliform-rule.

United States Environmental Protection Agency (US EPA). (1980). Urban storm water and combined sewer overflow impact on receiving water bodies, EPA 600/9-80-056. Retrieved from http:// nepis.epa.gov/Exe/ZyPURL.cgi?Dock ey=300058HL.TXT.

United States Environmental Protection Agency (US EPA). (2016). What is nonpoint source? Polluted Runoff: Nonpoint Source Pollution. Retrieved 
06 April 2016. Retrieved from http:// www.epa.gov.

US Geological Survey (USGS). (2015). Runoff (surface water runoff). The USGS Water Science School. Retrieved 08 April 2016. Retrieved from http:// www.water.usgs.gov/edu/runoff. html.

Washington State Department of Health. (2011). Coliform bacteria and drinking water. Department of Health, 331(181).

World Health Organization. (2008). Guidelines for drinking-water quality. Third Edition Incorporating the First and Second Addenda, Vol. 1, Recommendations (3rd Ed.). Retrieved January 18, 2016. Retrieved from http://www. who.int.
World Health Organization. (2011). Guidelines for drinking-water quality (4th Ed.). Retrieved January 18, 2016. Retrieved from http://www.who.int.

World Health Organization. Surface water abstraction, Fact Sheet 2.7. Retrieved 11 February 2016. Retrieved from http:// www.who.int.

World Health Organization. (2001). Indicators of microbial water quality. Water Quality: Guidelines, Standards and Health. Retrieved 29 March 2016. Retrieved from http://www.who.int.

Zhuikov, M. (2008). Scientists find bird and human E. coli in wild fish. Retrieved April 8, 2016. Retrieved from http:// www.seagrant.umn.edu. 